Review

\title{
Prospects for Hermetic Sealing of Scaled-Up Photoelectrochemical Hydrogen Generators for Reliable and Risk Free Operation
}

\author{
Sonya Calnan ${ }^{1, *}$, Stefan Aschbrenner ${ }^{1}$, Fuxi Bao ${ }^{1}$, Erno Kemppainen ${ }^{1}$, Iris Dorbandt ${ }^{1}$ \\ and Rutger Schlatmann 1,2 \\ 1 PVcomB, Helmholtz-Zentrum Berlin für Materialien und Energie GmbH, Schwarzschildstrasse 3, \\ 12489 Berlin, Germany; stefan.aschbrenner@helmholtz-berlin.de (S.A.); fuxi.bao@helmholtz-berlin.de (F.B.); \\ erno.kemppainen@helmholtz-berlin.de (E.K.); iris.dorbandt@helmholtz-berlin.de (I.D.); \\ rutger.schlatmann@helmholtz-berlin.de (R.S.) \\ 2 Hochschule für Technik und Wirtschaft Berlin HTW, Wilhelminenhofstraße 75A, 12459 Berlin, Germany \\ * Correspondence: sonya.calnan@helmholtz-berlin.de
}

Received: 1 October 2019; Accepted: 29 October 2019; Published: 1 November 2019

\begin{abstract}
Photo-electrochemical (PEC) systems have the potential to contribute to de-carbonation of the global energy supply because solar energy can be directly converted to hydrogen, which can be burnt without the release of greenhouse gases. However, meaningful deployment of PEC technology in the global energy system, even when highly efficient scaled up devices become available, shall only be a reality when their safe and reliable operation can be guaranteed over several years of service life. The first part of this review discusses the importance of hermetic sealing of up scaled PEC device provided by the casing and sealing joints from a reliability and risk perspective. The second part of the review presents a survey of fully functional devices and early stage demonstrators and uses this to establish the extent to which the state of the art in PEC device design address the issue of hermetic sealing. The survey revealed that current material choices and sealing techniques are still unsuitable for scale-up and commercialization. Accordingly, we examined possible synergies with related photovoltaic and electrochemical devices that have been commericalised, and derived therefrom, recommendations for future research routes that could accelerate the development of hermetic seals of PEC devices.
\end{abstract}

Keywords: photo-electrochemical; solar hydrogen generator; hermetic sealing; reliability; safety; scale-up

\section{Introduction}

Photo-electrochemical (PEC) water splitting cells have the potential to contribute to de-carbonation of the global energy supply because solar energy can be directly converted to hydrogen which can be burnt without the release of greenhouse gases. PEC devices absorb photons from sunlight and convert it into chemical fuels such as hydrogen, thus enabling the direct storage energy for use in times of insufficient solar irradiance, unlike purely photovoltaic devices. The photo-absorber material in the PEC device captures photons and uses those with high enough energy to move electrons from the valence band to the conduction band, creating a photo-voltage. The photo-generated electrons and holes are then transported to the interface between an electrode (which itself might be a photo-catalyst, or which is covered by a catalyst) and an electrolyte at which oxidative or reductive charge transfer reactions occur. The oxidative reaction, which consumes holes, takes place at the anode, while the reductive half reaction, which consumes electrons, occurs at the cathode. In the case of electrolysis of water, the products of the overall reaction are $\mathrm{H}_{2}$ (at the cathode) and $\mathrm{O}_{2}$ (at the anode). Apart from 
improving the long-term reliability of solar hydrogen generation systems to promote the widespread deployment of the technology, safe operation becomes more important especially because the first PEC systems are likely to be used for decentralised energy supply because of their small capacity, thus increasing the risk of injury and death. It is thus important to design the systems with reliability and risk in mind to achieve acceptance by the general public.

Much progress has been made in the material research of photo-absorbers as well as photo-catalysts and co-catalysts leading to improved energy conversion efficiencies. Additionally, the device design has advanced from three electrode test set-ups to fully functional devices, for which scale-up has become relevant. Previous reviews on PEC devices covered aspects such as monolithic cell concepts [1] as well as modelling and simulation to guide the design and implementation of cell designs with consideration of full functionality [2]. Another study provided an overview of the development of PEC cells for research purposes and gave suggestions for designs for suitable for practical application [3]. The authors also discussed the challenges of integrating both the photovoltaic and electrolysis functions into one unit and in scaling those devices to practically useful sizes. Since the electrochemical stability of both the photo-absorbers and (photo- and electro-) catalysts is still a challenge, other reviews have discussed possibilities to mitigate (electro-) corrosion in PEC devices [4,5]. Related reviews have compiled experimental demonstrations of solar PEC driven water-splitting devices with focus on the solar to hydrogen conversion efficiency and longevity from the perspective of (electro-) chemical stability [6,7]. Additionally, the progress in scale-up has been presented [7] and the technology readiness levels of different PEC pathways for deployment in the existing energy supply system [8] have been reviewed. All these topics play a role in informing the community about improvements required for the PEC technology to reach commercial maturity; however, none directly addresses the importance of designing the PEC for reliable and safe service.

As discussed above, numerous reports have been published on laboratory sized solar hydrogen generation devices, but these are rarely scaled up to commercially relevant prototypes. Additionally, although high solar to hydrogen (STH) conversion efficiencies have been attained by improving active materials, the technology readiness level (TRL) remains low because the devices fail to perform satisfactorily under realistic operating conditions. One of the reasons for this is the lack of low cost but robust materials for the device casing and sealing, which are important to ensure safe, reliable and durable operation of the device. The few reports that deal with PEC reliability, describe cell failure only in terms of degradation caused by electrochemical and/or photo- corrosion. Nandjou and Haussener discussed durability and reliability of PEC devices from the perspective of performance loss because of degradation by corrosion of active materials (photo-absorber, catalyst, polymer electrolyte) [5]. They also considered the conductive flow field plates, which in some cases form part of the casement, but their main focus was on the corrosion resistance and the electrical conductivity and not structural integrity and leak-free operation [5]. While contemporary research in other electrochemical devices, such as lithium-ion pouch cells, discrete electrolysers and fuels cells, explicitly address sealing and leakage problems in the context of safe operation and premature failure, the opposite is true for PEC devices. To date a review considering the structural integrity aspects of the PEC encasement and seals as well as the importance of the reliability and safety of operation in the development of PEC devices in view of commercialisation is lacking.

Therefore, the purpose of this contribution is to survey material choices and techniques for achieving encasement of fully functional PEC devices reported in the literature and to evaluate their strengths and weaknesses, from a materials point of view, to identify paths to future improvements. Developments in material choices, sealing techniques and qualification testing in the fields of battery, electrolyser and fuel cell technology shall also be briefly discussed in the context of how they can inform PEC scale up from the perspective of safety and reliability. This review shall differ from previous ones by focusing on the materials and engineering issues concerned with ensuring system durability to structural failure caused by mechanical or chemical degradation of the electrolysis encasement. Since 
leakages are a result of structural failure, it is important to critically analyse the materials used today and evaluate how reliability can be guaranteed in scaled up devices.

We limit our analysis and discussions herein to fully functioning PEC prototypes demonstrating non-assisted hydrogen generation with provisions made in the design for collection of product gases from separate reaction compartments. In other words, such prototypes are designed to separately (without leakage across the electrode separator or membrane) collect and channel the product gases out of the prototype so that they can be collected then stored and/or analysed separately as would be expected in the practical application. We relaxed the aforementioned criteria for demonstrator $\sim \mathrm{m}^{2}$ size devices, as there are hardly any reported in the literature.

\section{Background Information}

To start this review, we define the terminology used and introduce the central themes of this review, that is, the importance of hermetic sealing in PEC devices as well as the risks and hazards during operation of PEC devices, in case the hermetic sealing is no longer intact.

\subsection{Terminology and Definitions}

Solar photo-driven electrolysis involves the absorption of incident light by a material with a bandgap lower than the energy level of the incident photons, leading to charge carrier generation, followed by separation and transport of the photo-generated charge carrier to catalysts, which transfer the charge carrier transfer to a chemical reaction. Such a chemical reaction could be the splitting of for example, water into $\mathrm{H}_{2}$ and $\mathrm{O}_{2}$. Throughout this paper, we use the term "photoelectrochemical" (PEC) to define any cells in which light is absorbed and used to provide energy to drive an electrochemical reaction, following the suggestion by Bard [9]. Thus, our definition covers all systems in which the charge separation and transfer to the electrochemical reaction occurs by diffusion, e.g., in particulate systems, by the Helmholtz-mechanism in photocatalytic systems with a semi-conductor-electrolyte junction or by drifting under the influence of an electrical field existing across a semiconductor junction such as in a photovoltaic cell. However, it is limited to systems where both the photo-absorber and electrolysis reaction are intimately connected either thermally or electrically, or both, in such a way that the device is a single unit that cannot be physically separated without destroying the functionality. By this definition, we excluded designs where discrete Photovoltaic (PV) modules/cells are connected directly through cables or via voltage/power conditioning electronics to separate electrolysis cells or stacks.

\subsection{Thematic Concepts Underlying the Review}

In this section, we describe the central concept underlying this review, that is, hermetic sealing for the reliable and risk-free operation of PEC devices. Hermetic sealing refers to the enclosure of the entire PEC device in a structure that prevents both gases and liquids leaking into and out of it. Since electrolysers operate by electrochemical reactions involving liquid and gaseous phases, it is important to avoid leaks of these out of the device as well as ingress of contaminants into the system. Thus, leak-free operation requires that both the structural integrity of the casing and hermetic sealing, thereof, be maintained throughout the service life of the PEC device. Avoidance of leakages in PEC devices is crucial for safe operation because the main product hydrogen is highly diffusive through most materials, has a wide flammability range in mixtures with air or oxygen and a low ignition energy threshold.

\subsubsection{Importance of Hermetic Sealing in PEC Devices}

Failure of the encasement of the electrochemical reaction reactants and products, or of a seal to contain the gas product or electrolyte pressure within the space where it should be confined may cause physical leaks in PEC devices. Gas phase leaks involve hydrogen, oxygen or both, leaving the electrolyser cell or air from the ambient entering the system and contaminating the product gases. Gas 
leaks into the cell reduce the rate of production of hydrogen and thus the system's hydrogen generation efficiency. Furthermore, gas leaks out of the electrolyser into surroundings or across separators within the electrolyser can pose a safety hazard by accumulation of explosive mixtures of $\mathrm{H}_{2}$ and $\mathrm{O}_{2}$. Fluid phase leaks involve electrolytes flowing out of the of the PEC device. Leaks of electrolyte out of the cell can pose a safety hazard by release of corrosive alkaline/acidic electrolyte into the environment. Electrolyte leaks out of the cell also increase operation costs, for example, through replacement of lost electrolyte and collection as well as the need to safely dispose of spilt corrosive electrolyte.

A second type of leak is of a chemical nature and requires that the sealant is capable of blocking the transport of reactive species (ions or electrons) towards the materials in the device that would be prone to a chemical attack. When a material is exposed to an environment containing charged species with which it can chemically react, the resultant deterioration of the material is termed as corrosion. Anodic corrosion occurs when the material is oxidised while cathodic corrosion occurs when the cations in the material are reduced. Corrosion may result either in the deposition of material onto the attacked surface or a loss of material therefrom. From a structural point of view, deposition of material is more acceptable than the loss of material, which would inevitably lead to mechanical failure. However, generally corrosion, whether additive or subtractive, inevitably leads to the deterioration of the mechanical properties and thus effective sealing provided by the encasement and sealing materials.

By device casing, we refer to the structural components that enclose both the photo-absorber and electrochemically active materials within the PEC unit. The device casing tends to be composed of several different materials because on the illuminated side, a transparent material is required. However, since most low-cost transparent materials lack the mechanical strength required to withstand loading induced by pressure build-up and mass flows, the remaining portion of the casement that contains the electrolyte, and supports the fittings for reactant inflow and product gas extraction, is made of more robust materials such as polymers or metal. Because of the use of at least two different materials for the casing, some form of sealing is required at their joints.

Thus, the main function of the casing is to prevent the ingress of contaminants from the environment to the interior and escape of reactants and products to the exterior of the device, respectively. Because of the mass flow during the process, the electrolyser casing also serves as a structural support for the device by ensuring sufficient sealing even when the internal pressure differs from the external pressure. Where joints in the casing are unavoidable, these can be hermetically sealed using gaskets and o-rings, as well as with extruded or dispensed adhesives. These seals have thicknesses typically ranging from a few hundred micrometres to several millimetres. In addition to the seals used at joints in the body of the electrolyser, gas separators are stretched across the length of the electrolyser and are specifically intended to prevent gas cross-over from the hydrogen- and oxygen-evolution electrode, but a discussion of these is outside the scope of this review. The sealing integrity of both the edge seals and the casing is important to allow the electrolyser cell to withstand the pressure levels that develop during gas production, forced convection of electrolyte through the cell and compression of the electrolyser components to minimise electrical transport distances. To achieve all these functionalities, the proper choice of electrolyser casing materials, as well as the sealing material and technique, is essential to ensure safe and reliable operation of the solar hydrogen generator.

\subsubsection{Risks and Hazards Associated with PEC Operation}

Most risks associated with PEC operation involve the loss of containment of either the product gases or reactants. Hazards associated with PEC operation include mechanical impact, electrical shock, undesirable chemical reactions or fire related events.

Operational risks include performance drop, wastage and low utilization of inputs, while health and safety risks are those concerning injury and death of persons. Other risks are related to finance are loss of property by accidents such as $\mathrm{H}_{2}$ or $\mathrm{O}_{2}$ explosions or uncontrolled release of corrosive electrolyte, or loss of revenue caused by escape of product gas. Yet other risks have a societal aspect and include negative public perception of the technology due to fatal accidents and environmental pollution. 
A large catalogue of hazards associated to the use of hydrogen is presented and discussed elsewhere [10]. Hydrogen has a wide range of flammability in air $\left(4-75 \%\right.$ at $25{ }^{\circ} \mathrm{C}$ and 1 bar), has a relatively low ignition energy and can spontaneously ignite when suddenly released at high pressure. Additionally, because of the small size of the molecule, $\mathrm{H}_{2}$ can diffuse through containment materials and may cause embrittlement (structural degradation caused by initiation and growth of cracks which can lead to sudden fracture) in a variety of materials. Other hazards associated with hydrogen are rupture of containment due to internal overpressure or external mechanical shock and explosions. Usually explosions can be characterised by deflagration or detonation in which the combustion propagates at a velocity slower or faster, respectively, than that of sound. Detonation being accompanied by a forceful pressure shock poses a particularly serious safety risk.

Additionally, the unintentional release of oxygen to the environment can increase the risk of fire and/or explosions. If the amount of oxygen in a gas mixture exceeds $23.5 \%$ by volume, less heat is required to ignite most materials such that small sparks may start fires, the auto ignition energy of some materials is greatly reduced and materials tend to burn more intensively in oxygen-enriched environments [11]. Likewise, critically, the permissible $\mathrm{H}_{2} / \mathrm{O}_{2}$ gas mixture flammability ranges should not be exceeded in the vicinity of a hydrogen generation system. When polymeric encasements are used for the PEC device, the build-up of static charge should be avoided to reduce the possibility of ignition in case of oxygen leak.

\subsubsection{Reliability and Durability in the Context of PEC Device Operation}

Since sealing integrity is important for safety and product quality of PEC devices, the technology shall not advance to commercialisation unless the related challenges are solved. A proactive effort by those involved in the research and development of PEC devices to increase their reliability and to reduce risks associated with their operation at a pre-commercial stage, will speed up the time to deployment. Sathre et al. reported predictions of the net life cycle energy balance of different PEC systems based on lab scale devices scaled up to hypothetical systems of Megawatt (MW) capacity [12]. That study demonstrated that after STH efficiency, the life span of the PEC cells is an important factor for the primary energy balance, return on investment and energy payback time, from a life cycle perspective. The lifespan of such PEC cells would certainly depend on the durability against mechanical or chemical failure of the encasement and its seals throughout the system's service life. Leakages caused by failure of containment by the PEC also have economic and environmental implications. The failures not only result in an economic loss but also in risk of injury and contamination of the environment. The consequences of ignoring these aspects may affect user acceptance when fatalities occur in the early stages of deployment. Sealing integrity also has a relevance to the economic aspects of the system. Since device pricing models may include a premium for considerations, such as higher than average device performance and higher purity of the product gas, sealing integrity is essential for accurately determining the amount and quality of product gas generated so that the device manufacturer does not lose revenue and the customer receives fair value for money.

Thus, potential users of PEC systems expect a long service lifetime, trouble-free operation and predictable financial return on investment demanding that the devices be designed with reliability and durability in mind. Reliability in this context means how well the system performs its intended function under normal operating conditions. It is a measure of the system's resilience against gradual failure which leads to a gradual loss in functionality. In PEC device encasements, reliability failure could be caused by hydrogen embrittlement, oxidation by electrolyte or product gas, corrosion, erosion by multiphase turbulent flow, deformation by mechanical stress, among others. On the other hand, robustness/durability is the ability of the PEC device to maintain its functionality outside the operation conditions for which a system was designed. Durability is thus resilience against damage caused, for example, by sudden changes or gradually increasing mechanical loading, temperature or internal pressure; or impact by foreign objects. 


\section{General Considerations for Hermetic Sealing of PEC Devices}

In this section, we present the typical conditions under which PEC devices are expected to operate, then discuss possible failure modes that could cause loss of hermetic sealing during operation. We also identify safety issues that would arise when hermetic sealing is broken and discuss the demands on the materials used for hermetic sealing.

\subsection{Operating Conditions}

Operating conditions have a key impact on the integrity of the casement and seals of a PEC device. They affect the longevity of the device and place restrictions on the possible materials that can be used for the various components of the device. The operating conditions are, in turn, influenced by the parameter settings for the process and by the prevailing environmental conditions. The operating conditions expose the PEC devices to mechanical stress, temperature variations and potentially reactive chemicals, as well as to possible photo-induced degradation.

Environmental factors that influence the PEC device reliability and durability include diurnal and seasonal temperature variations, airborne pollutants and variations in mechanical loading caused by wind, rain, snow and hail. The severity of the environmental factors depends on the geographical location as well as local conditions. Generally, operations with environmental temperature extremes between $-20^{\circ} \mathrm{C}$ and $50{ }^{\circ} \mathrm{C}$ could be imagined for outdoor applications. Environmental thermal effects include thermal cycling because of diurnal variations in the sun's position, abrupt temperature changes, temperature extremes including freezing, as well as local heating. Other environmental conditions include chemically active airborne pollutants, such as salt near the sea, ammonia near agricultural buildings and acid rain, among others. Wind and snow cause stress through physical loading while hail causes shock impact. Further in desert regions, sand can erode and eventually cause the casing material to fail.

Process conditions of relevance to PEC devices such as the operating temperature, the electrolyte $\mathrm{pH}$, mass flow rates and operating pressure, among others, would also determine the approach used to ensure hermetic sealing. The process conditions vary according to the type of photo-absorber and catalysts used. The maximum operating temperature of a PEC device shall depend on whether or not active heating of the electrolyte is applied. To reduce the energy balance, most PEC devices rely on heating from the ambient such that the maximum operating temperature would not exceed $100{ }^{\circ} \mathrm{C}$, with the exception of concentrated PEC systems, where the operating temperature may well exceed this limit. The maximum operating pressure for PEC devices is likely to be relatively lower than that of discrete electrolysers, mainly because of the limitations of the casement material properties as shall be discussed later. The feed-water or electrolyte is usually fed to the electrolysis reaction through natural convection or forced flow, while reactions can cause bubble formation, which could act to erode the inner walls of the casing. Mass transport can also induce pressure differences within the casing while compression may increase the operating pressure above atmospheric pressure. The $\mathrm{pH}$ of the electrolysis reaction usually ranges from acidic, through neutral to alkaline. Highly alkaline ( $\geq 1.0 \mathrm{M} \mathrm{KOH})$ or acidic $\left(0.1-1 \mathrm{M} \mathrm{H}_{2} \mathrm{SO}_{4}\right.$ or solid sulphonated tetrafluorethylene-polymer with the brand name, Nafion ${ }^{\mathrm{TM}}$ ) electrolytes are preferred to reduce electrical transport losses in the electrolyser. Thus, the electrolyte determines the chemical environment to which the electrolyser components are exposed, and thus, reduces the scope of potential materials for the encasement and seals. If a material is susceptible to attack by the electrolyte, its chemical composition changes and may adversely affect its functionality. Additionally, since the hydrogen generation efficiency of electrolysis increases with temperature and with pressure, it is imperative that the sealants retain their functionality under these harsh conditions over an extended period of time. 


\subsection{Conceivable Failure Modes That Could Cause Loss of Hermetic Sealing}

Many phenomena occur simultaneously during PEC operation namely energy absorption, heat generation and dissipation, fluid flows, pressure drops, local $\mathrm{pH}$ gradients, local electrical field gradients, among others. The cumulative effects of the internal phenomena in the device as well as the influence of environmental conditions may sooner or later cause failures depending on their frequency and severity, and on the materials of the device components. Mechanical failure can be caused by excess pressure build-up within the device, thermal expansion and contraction, wind and/or snow loading, as well as impact by hail. Failure modes related to hermetic sealing in PEC are mainly those related to overstress and wear caused by normal operation or unexpected events, or both. Overstress failure includes yield and buckling, which occur when the support structure or joint of the casing is stressed beyond its mechanical strength by impact from, for example, hail in outdoor conditions, non-uniform distribution of stress caused by different coefficients of linear thermal expansion, build-up of pressure within the device, among others. Wear related failure modes include creep and fatigue. Creep refers to permanent deformation caused by the influence of constant mechanical stress (such as constant flow velocity, vibrations or compression at seals) and/or thermal stress. On the other hand, fatigue results from crack formation caused cyclic loading conditions (pressure, temperature, vibrations, etc.).

Erosion, corrosion and photodegradation are additional phenomena that can cause mechanical failure in the hermetic sealing of PEC devices. Erosion is a result of abrasion and wear caused by bubbles and fluid velocity internally and, by sand externally. Corrosion on the other hand is caused by chemical reactions between the PEC encasement and sealing materials with the electrolyte and the product gases internally and externally with salt, acid rain and ammonia.

Photodegradation occurs when incident light of sufficient photon energy catalyses a reaction between an oxidant or a reducing agent and the material of interest. Under dry conditions, certain polymeric materials are susceptible to breakage if their bonds causing embrittlement and cracking. On the other hand, when light exposure occurs in the presence of an aqueous medium, photo-corrosion may occur. Photo-corrosion is a light driven process caused by a photoactive semiconductor absorbing light of sufficient energy and using it to generate charged carriers that subsequently participate in detrimental reactions with the photo-absorber itself and/or adjacent components such as corrosion protection layers, joint seals or the walls of the electrolyte encasement. Photo-generated holes or electrons could participate in irreversible oxidation or reduction reactions by involving electrons or holes, respectively, donated by surrounding materials. The photo-corrosion of photo-absorbers and the adjacent functional thin films is the subject of extensive study [4-7] whose discussion exceeds the scope of the present paper. Our concern here is of possible photo-corrosion of the supporting structure and sealants of the PEC device. For such devices, photo-induced corrosion is possible on the outer walls of the metallic casement, if the metallic surface is covered by a spontaneously formed oxide film with the appropriate band-gap to absorb photons under daylight radiation and is simultaneously in contact with atmospheric moisture. Since the photo-corrosion of metal surfaces can happen over the entire $\mathrm{pH}$ range, this may be of concern for long-term operation under outdoor conditions. We are of the view that photo-corrosion of the interior walls is highly unlikely, since the metal is opaque such that illumination of the exterior shall have no effect on the possible chemical reaction between the inner walls of the PEC casing and the electrolyte that they contain. Additionally, since metal oxides tend to be wide band-gap materials, even if the active photo-absorber is semi-transparent, it is unlikely that short wavelength photons responsible for inducing photo-corrosion would reach the inner walls of the casement, behind it.

\subsection{Safety Issues}

As already pointed out, the main risks that can potentially occur during the operation of PEC devices are those resulting from a loss of containment of either the product gases and/or corrosive electrolyte. To minimise these risks, several standards exist to guide the design of safe electrolysis 
systems. For example, ISO 22734-1:2008 defines the construction, safety and performance requirement of electrolysers for indoor and outdoor non-residential use [13], while ISO 22734-2:2011 defines the same requirements for residential applications [14]. However, adaptations may be needed to consider the photovoltaic components of PEC devices.

Within the electrolysis casing, it is important that high gas purity is maintained to prevent the amount of $\mathrm{H}_{2}$ in $\mathrm{O}_{2}$ falling within the explosion range of 3.9-95.8 vol.\%. Note that this range is valid for operation at atmospheric pressure at $20^{\circ} \mathrm{C}$, but the lower and higher explosion limit decrease and increase, respectively, when operating temperature is raised from $20-80{ }^{\circ} \mathrm{C}$ [15] even at $1.0 \mathrm{bar}$. Moreover, at room temperature, the lower explosion limit of $\mathrm{H}_{2}$ in $\mathrm{O}_{2}$ increases with operating pressure between 1-50 bar, while the higher explosion limit reduces, then increases again within this pressure range [16]. Based on these observations, it is to be expected that when operating an electrolyser both at temperatures above $20^{\circ} \mathrm{C}$ and at pressures above 1.0 bar, especially the lower explosion limit may reduce. Although the PEC devices are designed to work outdoors, whereby the volume fraction of $\mathrm{H}_{2}$ may be kept below the lower explosion limit inside the electrolyser, sealing at the edges of the separator and the casement must prevent leakages to avoid explosive mixtures developing within the casement. The casement should ideally be strong enough to either contain hydrogen explosions or to limit damage caused thereby.

As the devices are scaled up, the quantity of reactants and products involved in the chemical reaction also increases, thus increasing the risks of hazards caused by loss of containment. For example, the lower flammability limit for $\mathrm{H}_{2}$ in air/oxygen mixture can be more quickly exceeded, more quantities of potentially corrosive electrolyte can be released into the environment and the mechanical damage caused by projectiles resulting from sudden mechanical failure of larger devices is likely to be more severe than for small laboratory test-set-ups. Guidelines for material properties to be considered when handling hydrogen are published elsewhere [10].

\subsection{Demands on PEC Device Encasement and Sealing Materials}

Since mechanical loads that exceed the strength of the supporting material potentially contribute to most failures in PEC, the casing should be mechanically strong (have a high tensile and compressive strength) to ensure structural stability and to prevent breakage. The chosen casing and sealing materials should also have a high yield strength to prevent fracture because of cycling loading caused by vibrations from flowing liquids and gas bubbles as well as temperature cycling from diurnal variations.

Toughness is the degree to which a material can resist elastic deformation and is required to prevent rapture caused by impact from either internal or external shock events. Elasticity is the ability of a material to completely and immediately recover from an imposed displacement on release of the load. Stiffer materials have a high Young's modulus and can bear higher loads before being elastically deformed. However, material strength is inversely proportional to toughness, and thus, a compromise should be made when choosing materials [17] for hermetic sealing. Unlike ductile materials, which undergo a permanent distortion (plastic deformation) beyond their elastic limit, brittle materials facture with very little plastic deformation. Ductility of the material for PEC device encasement is important because it allows for a margin of safety in design so that the device can survive unexpected events such as pressure build-up, impact or overloading without rupturing. Epoxies and glues at joints should also be highly ductile so that they can undergo large deformations before breaking or rupturing. In contrast, glassy materials being brittle can fail without warning when overloaded. The casement material should be also hard enough to reduce the effects of both internal and external erosion.

Materials with a low coefficient of thermal expansion are desirable to avoid build-up of stress caused by expansion and construction as a result of thermal cycling. For colder climates, mechanical stability to freeze-thaw cycles, is crucial. Wherever possible, the PEC encasement assembly should consist of materials with similar coefficients of linear thermal expansion to prevent the less expansive component from exerting strain on the other components after a change in temperature. One should 
note that the lower the product of thermal expansion and elastic modulus of a material, the more resistant it is to thermal shock.

The casement and sealing materials should be chemically compatible with the water electrolysis reactants and products. Where the encasement is composed of dissimilar metals, they should be chosen so that galvanic corrosion is avoided. Corrosion of the encasement weakens the structural integrity of the material and potentially introduces contaminants to the electrolysis reaction, thus reducing the performance. The material should be resistant to embrittlement by hydrogen and to oxidation. Additionally, the material should be resistant to anodic oxidation and cathodic reduction, especially if it is used to transport charges in the redox reaction, as is the case for metallic endplates.

While a high electrical conductivity of the encasement material is not mandatory, if polymers are used, considerations for the dielectric breakdown should be made in the event of sparks and/or voltage surges caused by faults.

\section{State of the Art in Hermetic Sealing of PEC Devices}

A variety of device designs have been reported in the literature with continuous improvements in energy conversion efficiency and short-term stability achieved by improved material properties of components directly involved in the PEC process namely the photo-absorber, electrocatalysts, electrolytes and electrode supports. Additionally, efforts have been made to reduce the material costs of such components in order to make PEC economically competitive with other forms of energy generation so as to accelerate entry into the energy market. Nevertheless, although the safety and reliable operation afforded by robust containment vessels will be important for the meaningful deployment of photo-electrochemical devices in the global energy system, the materials research for these components has been largely neglected in pertinent literature. For this purpose, it is important to identify which materials could potentially be used to design flow cells/containment vessels and their sealing, that are easily scalable and low cost and at the same time durable for tens of thousands of hours' service in chemically reactive species under fluctuating temperature and fluid velocity conditions.

\subsection{Compilation of Fully Functional PEC Systems}

Here, we present a compilation of reported PEC designs, which have promise for scale-up beyond laboratory prototypes. The data set is limited because the majority of laboratory scale solar cells area $\sim 5 \mathrm{~cm}^{2}$ are excluded from the scope of this review because since they are too small to warrant accurate quantification of gas production as previously observed [3] without careful design of the product gas separation. The images of a selection of fully functional PEC prototypes are presented in Figure 1a- $\mathrm{f}$ and for comparison, a square meter-sized demonstrator is presented in Figure 1g.

In all the devices shown, the electrical connection between the photo-absorber and the electrolysis process is contained within the encasement. There are generally three ways of sealing the joints, one is by using adhesives to glue the parts together (this work; [18]), the second is to use compression seals that are clamped by screws [19-21] and the third using adhesives supported by a metallic brace to maintain compression sealing [22]. The details of the devices presented in Figure 1, as well as those of a wider selection derived from the literature, are presented in Table 1. The entries are arranged in ascending order of the solar collection area. While the laboratory size prototypes operate purely from solar energy and have provisions for separately collecting $\mathrm{H}_{2}$ and $\mathrm{O}_{2}$, the demonstrators either require an additional external bias, or only consist of either a photo-anode or photocathode. 

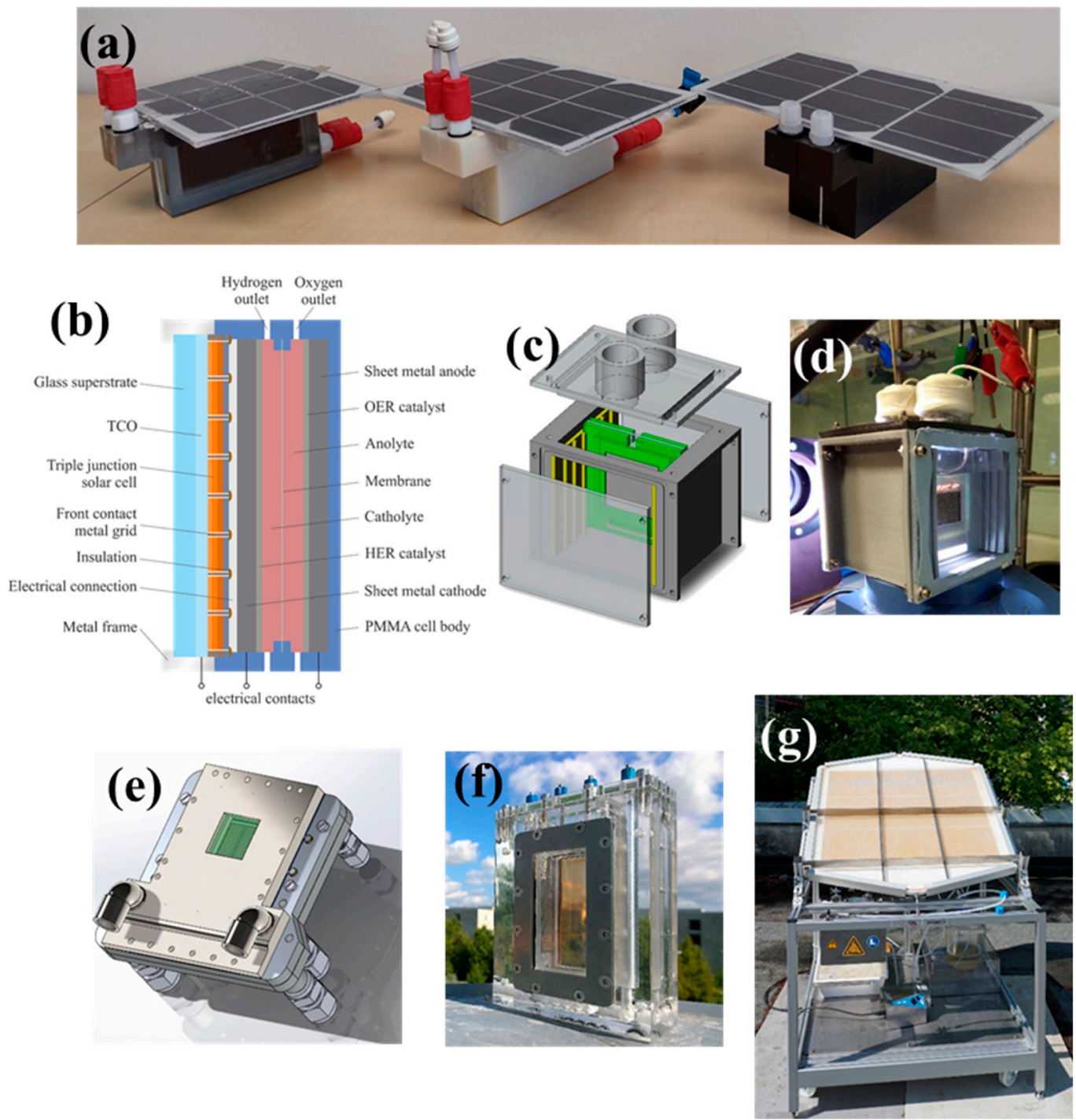

Figure 1. Images of a selection of fully functional photo-electrochemical (PEC) laboratory prototypes showing the different means of hermetic sealing used. PEC devices (a) with the body made out of various three-dimensional (3-D) printed acrylic based polymers and sealed using only epoxy and sealing gaskets in the authors' laboratory. Machined poly methyl methacrylate (PMMA) body (b) with edge sealing done using epoxy adhesive (image courtesy of F. Finger and J. Becker, Forschungszentrum Jülich, Germany); Drawing (c) and photograph (d) of a 3-D printed polylactic acid (PLA) encasement using screw compression with the peripheral of the glass window sealed with a reusable pressure sensitive adhesive (figures courtesy of Virgil Andrei, University of Cambridge, United Kingdom). Devices sealed using compressive pressure via clamping with bolts namely, (e) 3-D printed titanium aluminium vanadium alloy solar concentrated PEC, (image courtesy of Sophia Hausenner, Ecole Polytechnique Federal de Lausanne, Switzerland); (f) CoolPEC cell made from machine milled PMMA plates (figure courtesy of Tânia Lopes, University of Porto, Portugal) and (g) a large collection area demonstrator with sealing supported by metallic braces along the device edges (figure courtesy Michael Schwarze, Technical University of Berlin, Germany). 
Some of the small photo-aborbers with a solar collection area of less than $25 \mathrm{~cm}^{2}$ when combined with solar concentration systems produce significantly high amounts of hydrogen despite the small size of the reactor [21,23]. For these devices, the casing is comparatively highly advanced compared to the other listed laboratory prototypes of roughly the same size that were designed for operation under one sun $[19,24-28]$. The design of intermediate sized prototypes for 1 sun operation of a solar collection area larger than $25 \mathrm{~cm}^{2}$ but smaller than $100 \mathrm{~cm}^{2}$ have full functionality, but lower cost casing materials were used. The larger size of these devices somewhat increases the confidence in the $\mathrm{H}_{2}$ production measurements as well as the scalability although leakages cannot be ruled out.

In the next category are somewhat larger prototypes measuring at least $200 \mathrm{~cm}^{2}$ but still smaller than $500 \mathrm{~cm}^{2}$ ([20], this work). This size lies in between the laboratory prototypes and the demonstrators and the reported devices were designed for separate generation and collection of the product gases. However, since the prototypes are too large for typical continuous solar simulator, these devices could only be characterised using natural sunlight, as was the case for the demonstrators. The first one combining a PEC-PV hybrid (with a solar collection area of roughly $200 \mathrm{~cm}^{2}$ ) with solar concentration was developed in the PECDEMO project [29] based on the modular design (Figure 1f) published by Villanova et al. [20]. Another design, for which three different units are shown in Figure 1a, has been developed at the Helmholtz Zentrum Berlin (HZB) with a solar collection area of $294 \mathrm{~cm}^{2}$.

One of the demonstrators with a PEC collection area of $820 \mathrm{~cm}^{2}$ was used to generate $\mathrm{H}_{2}$ to feed an ammonia generator; however, it required an additional bias provided by a separate $\mathrm{PV}$ cell to power the full water splitting reaction [30]. In that system, natural sunlight was split such that wavelengths from 280-700 nm were directed to the PEC and the rest to the PV device with only a fraction of the aperture area $\left(200 \mathrm{~cm}^{2}\right)$ were illuminated by the concentrated sunlight. Another demonstrator also shown in Figure $1 \mathrm{~g}$ with a solar collection area of $910 \mathrm{~cm}^{2}$ comprised a particulate photocathode used with a hole scavenger to support the hydrogen evolution reaction (HER) but without provision for the oxygen evolution reaction (OER) [22]. A later particulate system with a collection area of $1.0 \mathrm{~m}^{2}$ used $\mathrm{SrTiO}_{3}: \mathrm{Al}$ with a co-catalyst in pure water and produced both $\mathrm{H}_{2}$ and $\mathrm{O}_{2}$ although no provisions were made for gas separation [31]. In a further demonstrator, several $\mathrm{BiVO}_{4}$ photoanodes assisted by silicon $\mathrm{PV}$ modules were assembled to make a system with a collection area of $1.6 \mathrm{~m}^{2}$ for which the authors reported a hydrogen production rate of $3 \mathrm{~g} / \mathrm{h}$, but did not disclose the details of the construction [32]. The table clearly illustrates the gap in functionality between prototypes and demonstrators of the roughly square meter size and thus the challenge of designing commercially relevant PEC devices. 
Table 1. Survey of state of the art PEC laboratory prototypes and demonstrators listing casing materials and edge sealing techniques.

\begin{tabular}{|c|c|c|c|c|c|c|c|c|}
\hline $\begin{array}{l}\text { Solar Collection } \\
\text { Area }\left(\mathrm{cm}^{2}\right)\end{array}$ & $\begin{array}{c}\text { Rate of } \mathbf{H}_{2} \\
\text { Production } \mathrm{g} / \mathrm{h}\end{array}$ & STH & Photoabsorber; & $\begin{array}{l}\text { Electrolyte; } \\
\text { OER; HER }\end{array}$ & $\begin{array}{l}\text { Structural Material } \\
\text { of Casing }\end{array}$ & $\begin{array}{l}\text { Edge Sealing Material } \\
\text { and Technique }\end{array}$ & Figure & $\begin{array}{c}\text { Year } \\
\text { [Reference] }\end{array}$ \\
\hline $\begin{array}{l}0.36 \text { (PV cell) } 90.7 \\
\text { (Fresnel lens) }\end{array}$ & $\begin{array}{l}153 \times 10^{-3} \\
\text { (252 suns) }\end{array}$ & $\sim 19$ & III-V dual junction & $\begin{array}{l}\text { Nafion; Ir; } \\
\text { carbon } \\
\text { supported Pt }\end{array}$ & $\begin{array}{l}\text { Titanium anode plate } \\
\text { clamped with } \\
\text { polyphenylene sulfide } \\
\text { (PPS) cathode plate. }\end{array}$ & $\begin{array}{l}\text { Screw compressed o-rings of } \\
\text { undisclosed material }\end{array}$ & $-/-$ & $\begin{array}{l}2017 \\
{[23]}\end{array}$ \\
\hline 1 & $98.2 \times 10^{-3}$ & 8.6 & $\begin{array}{l}\mathrm{GaAs} / \mathrm{InGaP} \\
\text { photoanode }\end{array}$ & $1.0 \mathrm{M} \mathrm{KOH}$ & $\begin{array}{l}\text { 3-D printed acrylic with } \\
\text { a quartz window }\end{array}$ & $\begin{array}{l}\text { Fluorosilicone O-ring seals } \\
\text { clamped using bolts and/or } \\
\text { epoxy (Loctite 9460, Hysol) }\end{array}$ & $-/-$ & $\begin{array}{r}2015 \\
{[24]}\end{array}$ \\
\hline 1 & $323 \times 10^{-6}$ & 10.6 & $\mathrm{InGaP} / \mathrm{GaAs} / \mathrm{Ge}$ & $\begin{array}{l}\text { Nafion XL-100 } \\
\text { in } 1 \mathrm{MH}_{2} \mathrm{SO}_{4} ; \\
\mathrm{IrO}_{x} ; \mathrm{Pt}\end{array}$ & $\begin{array}{l}\text { Machined acrylic with } \\
\text { quartz window }\end{array}$ & $\begin{array}{c}\text { Viton O-ring clamped using } \\
\text { bolts; window and flow fittings } \\
\text { sealed with Epo-Tek } \\
\text { epoxy } 302-3 \mathrm{M} \\
\end{array}$ & $-/-$ & $\begin{array}{l}2017 \\
{[26]}\end{array}$ \\
\hline 1 & $386 \times 10^{-6}$ & 12.6 & $\mathrm{GaInP}_{2} / \mathrm{InGaAs} / \mathrm{Ge}$ & $\begin{array}{l}\text { Nafion } 115-100 \\
\text { in } 1 \mathrm{MH}_{2} \mathrm{SO}_{4} \\
\mathrm{Ir}_{x} ; \mathrm{Pt}\end{array}$ & $\begin{array}{l}\text { PMMA plates with } \\
\text { quartz window }\end{array}$ & $\begin{array}{l}\text { Electrolysis compartment } \\
\text { sealed using screw compressed } \\
\text { silicone seals; Seal between } \\
\text { window and PV device, and } \\
\text { electrolysis cell used an epoxy } \\
\text { mix consisting of Loctite 9460, } \\
\text { Hysol and EPO-TEK }{ }^{\mathrm{TM}}\end{array}$ & $-/-$ & $\begin{array}{l}2019 \\
{[27]}\end{array}$ \\
\hline 4 & $\begin{array}{c}230 \times 10^{-3} \text { at } 117 \\
\text { suns; } 1.09 \text { at } 473.54 \\
\text { suns }\end{array}$ & 19 & $\begin{array}{l}4 \text { cells in parallel } \\
\text { (InGaP-InGaAs-Ge) }\end{array}$ & $\begin{array}{l}\text { Nafion } 115 \text { in } \\
\text { pure water; } \\
\text { IrRuO }_{x} / \mathrm{Pt}\end{array}$ & $\begin{array}{l}\text { (3-D)-printed titanium } \\
\text { alloy } \mathrm{Ti}_{6} \mathrm{Al}_{4} \mathrm{~V} \text { with } \\
\text { glass window for } \\
\text { illumination }\end{array}$ & $\begin{array}{c}\text { Screw compressed } \\
\text { (undisclosed material) seals, } \\
\text { epoxy seal between electrolysis } \\
\text { chamber and PV cell }\end{array}$ & $1^{\text {(e) }}$ & $\begin{array}{l}2019 \\
{[21]}\end{array}$ \\
\hline 10 & $45.2 \times 10^{-6(b)}$ & 0.15 & $\begin{array}{l}\text { Lead halide } \\
\text { perovskite-BiVO } \\
\text { tandem }\end{array}$ & $\begin{array}{c}0.1 \mathrm{M} \mathrm{KBi}, \\
\mathrm{K}_{2} \mathrm{SO}_{2}(\mathrm{pH} 8.50)\end{array}$ & $\begin{array}{l}\text { 3-D printed Polylactic } \\
\text { acid with acrylic } \\
\text { window }\end{array}$ & $\begin{array}{l}\text { Window sealed with soft } \\
\text { adhesive Blu Tack }\end{array}$ & $\begin{array}{l}1^{\text {(c) }} \\
1^{\left({ }^{\prime}\right)^{\prime}}\end{array}$ & $\begin{array}{l}2018 \\
{[19]}\end{array}$ \\
\hline 26.6 & $5.1 \times 10^{-3(c)}$ & 6.2 & $\begin{array}{l}\mathrm{GaInP}_{2} / \mathrm{GaAs} / \mathrm{Ge} \\
\mathrm{PV} \text { cells; }\end{array}$ & $\begin{array}{l}\text { 1.0 M potassium } \\
\text { borate buffer } \\
\text { ( } \mathrm{pH} 9.3), \mathrm{Pt}, \mathrm{Pt}\end{array}$ & $\begin{array}{l}\text { 3-D printed (Fullcure } \\
\text { RGD720) polymer with } \\
\text { glass window }\end{array}$ & Not disclosed & $-/-$ & $\begin{array}{l}2014 \\
{[28]}\end{array}$ \\
\hline$\sim 30(\mathrm{~d})$ & $13.9 \times 10^{-6}$ & $0.24 \%$ & $\begin{array}{l}\mathrm{WO}_{3} / \mathrm{FTO} / \mathrm{p}+\mathrm{n} \mathrm{Si} \\
\text { photo-anode and } \\
\mathrm{Pt} / \mathrm{TiO} / \mathrm{Ti} / \mathrm{n}+\mathrm{p} \\
\mathrm{Si} \text { photocathode }\end{array}$ & $\begin{array}{c}\text { Nafion }{ }^{(\mathrm{e})} ; 1.0 \mathrm{M} \\
\mathrm{HClO}_{4}\end{array}$ & $\begin{array}{l}\text { 3-D printed PMMA like } \\
\text { polymer (RGD720) } \\
\text { Glass window }\end{array}$ & $\begin{array}{c}\text { Adhesive epoxy Loctite 9460, } \\
\text { Hysol }\end{array}$ & $-/-$ & $\begin{array}{l}2015 \\
{[25]}\end{array}$ \\
\hline
\end{tabular}


Table 1. Cont.

\begin{tabular}{|c|c|c|c|c|c|c|c|c|}
\hline $\begin{array}{l}\text { Solar Collection } \\
\text { Area }\left(\mathrm{cm}^{2}\right)\end{array}$ & $\begin{array}{c}\text { Rate of } \mathrm{H}_{2} \\
\text { Production } \mathrm{g} / \mathrm{h}^{(\mathrm{a})}\end{array}$ & STH & Photoabsorber; & $\begin{array}{l}\text { Electrolyte; } \\
\text { OER; HER }\end{array}$ & $\begin{array}{l}\text { Structural Material } \\
\text { of Casing }\end{array}$ & $\begin{array}{l}\text { Edge Sealing Material } \\
\text { and Technique }\end{array}$ & Figure & $\begin{array}{c}\text { Year } \\
\text { [Reference] }\end{array}$ \\
\hline 50 & Not measured & $0.64^{(\mathrm{f})}$ & $\begin{array}{l}\text { Hematite with two } \\
\text { silicon PV cells } \\
\text { heterojunction } \\
\text { solar cells, }\end{array}$ & $\begin{array}{l}1.0 \mathrm{M} \mathrm{KOH} ; \text { not } \\
\text { disclosed }\end{array}$ & $\begin{array}{l}\text { PMMA casing, stainless } \\
\text { steel frames supporting } \\
\text { front quartz window } \\
\text { and rear glass } \\
\text { photo-electrode } \\
\text { substrate }\end{array}$ & $\begin{array}{l}\text { Sealing via clamping gaskets } \\
\text { with screws }\end{array}$ & $1^{(\mathrm{f})}$ & $\begin{array}{l}2018 \\
{[20]}\end{array}$ \\
\hline 64 & $\begin{array}{c}24.5 \times 10^{-3} \text { at } \mathrm{AM} \\
1.5 \mathrm{G}\end{array}$ & 4.8 & $\begin{array}{l}\text { Multi-junction thin } \\
\text { film silicon based } \\
\text { PV cells }\end{array}$ & $1.0 \mathrm{M} \mathrm{KOH}$ & $\begin{array}{l}\text { Machined PMMA and } \\
\text { glass window substrate } \\
\text { for the photo-absorber }\end{array}$ & $\begin{array}{l}\text { Polyether ether ketone (PEEK) } \\
\text { o-rings, clamping with epoxy }\end{array}$ & $1^{\text {(b) }}$ & $\begin{array}{l}2017 \\
{[18]}\end{array}$ \\
\hline $\begin{array}{l}200 \text { (combined PEC } \\
\text { area) }\end{array}$ & $\begin{array}{l}13.6 \times 10^{-6} \text { at } 17.5 \\
\text { concentration }(\mathrm{g})\end{array}$ & $-/$ & $\begin{array}{c}\text { Four sets in } \\
\text { tandem each } \\
\left(\mathrm{BiVO}_{4} / \mathrm{BiVO}_{4} \text { in }\right. \\
\text { series with a silicon } \\
\text { heterojunction } \mathrm{PV} \\
\text { cell }\end{array}$ & $\begin{array}{c}0.5 \mathrm{M} \mathrm{K}_{2} \mathrm{SO}_{2} \\
\text { with } 0.1 \mathrm{M} \\
\mathrm{K}_{2} \mathrm{HPO}_{4} / \mathrm{K}_{2} \mathrm{PO}_{4} \\
(\mathrm{pH} 7) ; \text { not } \\
\text { disclosed }\end{array}$ & $\begin{array}{c}\text { PMMA casing, stainless } \\
\text { steel frames supporting } \\
\text { front quartz window } \\
\text { and rear glass } \\
\text { photo-electrode } \\
\text { substrate; PMMA } \\
\text { casing protected on the } \\
\text { illuminated side from } \\
\text { overheating by } \\
\text { concentrated sunlight } \\
\text { using a } \\
\text { PTFE/aluminium shield }\end{array}$ & $\begin{array}{l}\text { Sealing via clamping gaskets } \\
\text { (undisclosed material) with } \\
\text { screws }\end{array}$ & $-/-$ & $\begin{array}{l}2017 \\
{[29]}\end{array}$ \\
\hline 294 & $44.1 \times 10^{-3}(\mathrm{~h})$ & $6-10$ & $\begin{array}{l}\text { Three silicon } \\
\text { heterojunction PV } \\
\text { cells in series; }\end{array}$ & $\begin{array}{c}1.0 \mathrm{M} \mathrm{KOH} \\
\mathrm{NiFeO}_{x}, \mathrm{NiMo}\end{array}$ & $\begin{array}{l}\text { 3-D printed PMMA } \\
\text { based Veroclear with } \\
\text { solar glass window }\end{array}$ & $\begin{array}{l}\text { LOCTITE EA9492 epoxy used } \\
\text { to seal joint with PV module } \\
\text { and joints of electrolysis cell }\end{array}$ & $1^{\text {(a) }}$ & $\begin{array}{l}2019 \\
\text { [This work] }\end{array}$ \\
\hline
\end{tabular}


Table 1. Cont.

\begin{tabular}{|c|c|c|c|c|c|c|c|c|}
\hline $\begin{array}{l}\text { Solar Collection } \\
\text { Area }\left(\mathrm{cm}^{2}\right)\end{array}$ & $\begin{array}{c}\text { Rate of } \mathrm{H}_{2} \\
\text { Production } \mathrm{g} / \mathrm{h} \text { (a) }\end{array}$ & STH & Photoabsorber; & $\begin{array}{l}\text { Electrolyte; } \\
\text { OER; HER }\end{array}$ & $\begin{array}{l}\text { Structural Material } \\
\text { of Casing }\end{array}$ & $\begin{array}{l}\text { Edge Sealing Material } \\
\text { and Technique }\end{array}$ & Figure & $\begin{array}{c}\text { Year } \\
\text { [Reference] }\end{array}$ \\
\hline $\begin{array}{c}820 \text { (PEC cell } \\
\text { aperture); } \\
8760 \text { (Fresnel lens) }\end{array}$ & $\begin{array}{l}16.8 \times 10^{-3} \text { at } 12 \\
\text { suns }^{(\mathrm{i})}\end{array}$ & $-/-$ & $\begin{array}{c}\mathrm{Cu}_{2} \mathrm{O} \\
\text { photocathode, }\end{array}$ & $\begin{array}{l}\text { Nafion, } \mathrm{IrRuO}_{\mathrm{x}} \\
\text { Platinum black }\end{array}$ & $\begin{array}{l}\text { PMMA end plates with } \\
\text { Acrylonitrile Butadiene } \\
\text { Styrene (ABS) frames } \\
\text { supported by HDPE } \\
\text { outer casing; Acrylic } \\
\text { window }\end{array}$ & $\begin{array}{l}\text { Nitrile rubber gaskets with } \\
\text { bolted compression clamping }\end{array}$ & & $\begin{array}{l}2017 \\
{[30]}\end{array}$ \\
\hline 910 & $8.3 \times 10^{-3(\mathrm{j})}$ & 0.12 & $\begin{array}{c}\mathrm{C}_{3} \mathrm{~N}_{4} \\
\text { photocathode; }\end{array}$ & $\begin{array}{c}\mathrm{H}_{2} \mathrm{O} \text { with } 10 \% \\
\text { vol. } \\
\text { Triethanolamine }\end{array}$ & $\begin{array}{l}\text { Teflon plate, stainless } \\
\text { steel and PMMA } \\
\text { window }\end{array}$ & Metal braces & $1^{(\mathrm{g})}$ & $\begin{array}{l}2015 \\
{[22]}\end{array}$ \\
\hline 10,000 & $90.7 \times 10^{-3(\mathrm{k})}$ & 0.4 & $\mathrm{SrTiO}_{3}: \mathrm{Al}$ & Water; $\mathrm{RhC}_{\mathrm{r}} \mathrm{O}_{\mathrm{x}}$ & $\begin{array}{l}\text { PMMA plates as } \\
\text { window and rear } \\
\text { support }\end{array}$ & Not disclosed & $-/-$ & $\begin{array}{l}2018 \\
{[31]}\end{array}$ \\
\hline 16,000 & $3^{(1)}$ & 3 & $\begin{array}{l}\text { CoPi catalyst on } \\
\text { BiVO }_{4}: \text { Mo and Co } \\
\text { photocathode; }\end{array}$ & Not disclosed & Not disclosed & Not disclosed & $-/-$ & $\begin{array}{c}2017 \\
{[32]}\end{array}$ \\
\hline
\end{tabular}

(a) Estimated value since for all cases, that the gas temperature was assumed to be $25^{\circ} \mathrm{C}$. ${ }^{\text {(b) }}$ Estimated using reported values of operating current density $=0.23 \mathrm{~mA} / \mathrm{cm}^{2} ; 52.2 \%$ Faradaic efficiency. (c) Calculated from the reported $9.7 \mathrm{~mA} / \mathrm{cm}^{2}$ operating current for a solar collection area of $26.6 \mathrm{~cm}^{2}$ and under the assumption of $100 \%$ Faradaic efficiency. (d) Size of photoabsorbers was not disclosed; thus, the value was derived from the window size of $50 \mathrm{~mm} \times 60 \mathrm{~mm} \times 1 \mathrm{~mm}$. (e) Nafion is a type of solid proton exchange membrane made from perfluorosulfonic acid/ polytetrafluoroethylene co-polymer. ${ }^{(\mathrm{f})}$ Calculated from the reported $0.45 \mathrm{~mA} / \mathrm{cm}^{2}$ operating current and under the assumption of $100 \%$ Faradaic efficiency. ${ }^{\text {(g) }}$ Measured under natural sunlight but intensity was not specified. (h) Measured under natural sunlight at $800 \mathrm{~W} / \mathrm{m}^{2}$ with an ambient temperature of $27.5^{\circ} \mathrm{C}$. ${ }^{\text {(i) }} \mathrm{Cold}$ mirrors split natural concentrated sunlight resulting in an incident spectrum on the PEC of $280-700 \mathrm{~nm}$. The incident global irradiance on the Fresnel lenses was $936.59 \mathrm{~W} / \mathrm{m}^{2}$ and the ambient temperature at ground level was $\sim 15{ }^{\circ} \mathrm{C}$. ${ }^{(j)}$ Only the photocathode demonstrated with 10 vol.\% triethanolamine was used as a hole scavenger. Hydrogen production rate derived from reported average rate of $0.1 \mathrm{~L} /\left(\mathrm{m}^{2} \mathrm{~h}\right)$. $(\mathrm{k})$ Measured under natural sunlight intensity, which varied from $650-750 \mathrm{~W} / \mathrm{m}^{2}$. (l) Additional external bias from silicon PV cells mounted on the same rack. 
Poly methyl methacrylate (PMMA), also known as acrylic and by tradenames such as Plexiglas and Perspex, to name a few, appears to be the most widely used material for the PEC device casing. The PMMA in form of plates was used either for structural support $[18,20,24-27,29]$ or as an illumination window $[19,22,32]$ or both $[30,31]$. PMMA is probably a material of choice because of its being easy to machine, its relatively high mechanical strength, low cost and ultra violet radiation resistance.

Additionally, a variety of polymers, mainly proprietary composites for 3-D printing have been used to fabricate PEC device encasements for example, Fullcure RGD720, a photopolymer [28], polylactic acid based composite $[19,22]$ as well as several PMMA-based composites ([24,25]; this work). 3-D printed flow plates and casements can be used for rapid prototyping, but despite the potential for low cost production, issues remain regarding the cost of the filaments, the longevity, especially of the polymeric components, and possible contaminants from the printing filaments since these are usually proprietary recipes. The three devices shown in Figure 1a were made at the Helmholtz Zentrum Berlin, (HZB) Germany under the PECSYS project, with the electrolysis encasement made out of different 3-D printed PMMA based polymer composites (left) VeroClear, RGD810; (centre) Objet-RGD525-High-Temperature-White and (right) VeroBlackPlus, RGD875 [33].

While the majority of 3-D printed polymer encasements in the literature are used with acidic and neutral electrolytes, in our laboratory, designs were made for alkaline (high $\mathrm{pH}$ ) PEC operation with different levels of success. Depending on the type of non-platinum group catalyst used, the solar irradiance and ambient temperature, solar to hydrogen efficiency values lay between $4-10 \%$ relating to a photon collection area normalised hydrogen production rate of 1.0-2.0 g $-\mathrm{H}_{2} /\left(\mathrm{h} \mathrm{m}^{2}\right.$ ) (to be published elsewhere). Thus far, the left hand device made using VeroClear, RGD810 based on PMMA has shown the best thermo-mechanical stability. Contrarily, the casing of the centre device using Objet-RGD525-High-Temperature-White, cracked after several tens of hours of intermittent operation and the right hand device using VeroBlackPlus, RGD875 tended to soften when the PV module temperature rose above $\sim 40^{\circ} \mathrm{C}$, causing a leakage of electrolyte at the joint between the PV module and the electrolysis casing.

Unlike polymers, metals have a high thermal conductivity allowing heat transfer between components thus avoiding over-heating; moreover, they retain their mechanical strength at high temperatures. Thus, for high solar concentration, metallic casement materials seem to be the preferred material in the form of machined plates [23] or as 3-D printed $\mathrm{Ti}_{6} \mathrm{Al}_{4} \mathrm{~V}$ alloy [21]. In another design, aluminium reflector plates with a PTFE insert were used to protect the PMMA casing of a prototype from overheating during solar concentration $\sim \times 18$ [30].

Since the use of two different materials is unavoidable, the window glass for illumination and the rest of the casing with a less rigid material, attaining a hermetic seal is more challenging for these devices than for discrete electrolysers. Materials for the transparent window include in ascending order of cost, PMMA [19,30,31], glass ([18,21,25,28], this work]) and quartz [20,24,26,27,29], to illuminate the photo-absorber. However, because these materials have poor compression strength, they tend to shatter easily and are thus incompatible with clamped seals that employ screws. The front glass of the PV module of left-hand PEC device in Figure la was shattered by the compression force during clamping just after the adhesive was applied illustrating the incompatibility of glassy transparent components of the encasement with compression stress required for hermetic sealing. Furthermore, glass has the disadvantage of a rather low thermal expansion coefficient and low thermal conductivity and thus can easily shatter under high thermal loading in a PEC system [21].

Epoxy resins have been used to seal against electrolyte leakage at the joint between PV and electrolysis cell $([21,26]$, this work) and to fix the inlet and outlet flow ports into the casing [26]. However, the seals made using epoxy between the PV cell and the electrolysis cell are prone to failure and may not be water tight as we experienced and as was reported by others [21]. This is because the quality (inclusion of air pockets) of the applied adhesive varies from run to run if applied manually. Additionally, from our experience, the seals at the flow ports are prone to leaking probably as a result of vibrations from the flowing electrolyte. 
The choice of materials for o-rings and/or gaskets is more varied and includes Viton, a fluoroelastomer [27] and polyether ether ketone (PEEK) [29] for both alkaline and acidic environments. For alkaline PEC devices fluorosilicone [25] and ethylene propylene diene EPDM [this work] gaskets have been reported while silicone elastomer [28] gaskets were used for PEC devices with PEM. These materials have already been engineered for more demanding applications than those typical of PEC devices and thus can be considered well developed. The remaining challenge is to find techniques of applying uniform and sufficient compression either by clamping or adhesion without damaging the brittle but essential illumination window.

There have been a few explicit accounts of challenges associated with choice of suitable materials for casements in functioning devices. For example, Walczak et al. reported the parasitic absorption of $\mathrm{O}_{2}(\mathrm{~g})$ onto the internal surface of the chassis and the epoxy materials that were used to construct a fully integrated, acid stable and scalable louvered solar driven water splitting system [25]. Becker et al. reported $\mathrm{H}_{2}$ crossover in a PEC device encased in metal supported PMMA with edge sealing using polyether ether ketone (PEEK) o-rings fixed in place with a commercial epoxy resin (Hysol 9483, Henkel) [18]. They attributed the $\mathrm{H}_{2}$ crossover to possible leakage across the membrane or at its edges where the o-rings separated the two chambers from each other. In a follow-up paper, Welter et al., reporting on the same device set-up, acknowledged that fluctuating irradiance and temperature might affect the mechanical stability of the EC housing [34]. Despite performing laboratory stability tests with simulated solar day and night cycles, no conclusive results on the effects of dynamic loading on mechanical stability were presented.

Additionally, Tembhurne et al. [21] reported that a commercial thermally conductive epoxy resin used to glue the rear of the PV cell to the anode in their concentrated PEC design was not water tight. A commonality for the aforementioned reports is that when epoxy was used, either gas or liquid leaks happened. We observed the same effect in our laboratory, whereby the joint between the back of the PV module and the electrolyser casing developed an electrolyte leak after several hours of exposure to illumination that caused the PV module to heat to $\sim 50{ }^{\circ} \mathrm{C}$. This is likely caused by the different coefficients of linear thermal expansion of the PV cover glass, the electrolyser casing and the dried epoxy applied to the joint to fix the two together. It is also possible that the dried epoxy did not have sufficient viscoelasticity to compensate for the different coefficients of linear expansion of the more rigid parts. In contrast, joints sealed using gaskets or o-rings made out of soft thermoplastics, e.g., viton or PTFE or PEEK clamped by screws tend to be more leak tight as evidenced by their wide spread use in discrete electrolysers.

\subsection{Critique of Candidate Materials for Hermetic Sealings}

Candidate materials for hermetic sealing can be identified by examining the properties of materials used for the casing and seals of PEC devices reported in the literature. They can be also identified by surveying the established materials used in the technologically more mature but related fields of electrolysers, fuel cells and photovoltaic modules. Table 2 lists selected properties of materials that have been used in the past for PEC devices, electrolysers, fuel cells and photovoltaic modules. 
Table 2. Mechanical, thermal and chemical properties of materials that have been used in the past for electrolysers, fuel cells and photovoltaic modules. All data taken from Cardarelli [35] except for $\mathrm{H}_{2}$ permeability of metals [36] and polymers [37].

\begin{tabular}{|c|c|c|c|c|c|c|c|c|c|}
\hline Materials & $\begin{array}{l}\text { Density } \\
\left(\mathrm{kg} / \mathrm{m}^{-3}\right)\end{array}$ & $\begin{array}{l}\text { Elastic/Young's } \\
\text { Modulus } E \\
\quad \text { (GPa) }\end{array}$ & $\begin{array}{l}\text { Compression/Bulk } \\
\text { Modulus, K (GPa) }\end{array}$ & $\begin{array}{c}\text { Ultimate } \\
\text { Tensile Stress } \\
\sigma_{\text {UTS }} \text { (MPA) }\end{array}$ & $\begin{array}{c}\text { Impact } \\
\text { Energy per } \\
\text { Unit Width } \\
(\mathrm{J} / \mathrm{m})^{(\mathrm{a})}\end{array}$ & $\begin{array}{c}\text { Coefficient of } \\
\text { Linear Thermal } \\
\text { Expansion, } \alpha_{\mathrm{L}} \\
\left({ }^{\circ} 10^{-6} \mathrm{~K}^{-1}\right)\end{array}$ & $\begin{array}{c}\text { Min.- Max.- } \\
\text { Operating } \\
\text { Temperature } \\
\left({ }^{\circ} \mathrm{C}\right)\end{array}$ & $\begin{array}{c}\mathrm{H}_{2} \text { Permeability } \\
\left.\text { (Mole } \mathrm{H}_{2} / \mathrm{m} \mathrm{s} \mathrm{MPa}\right] \\
\sim 300 \mathrm{~K}, 1 \mathrm{~Pa}\end{array}$ & $\begin{array}{c}\text { Chemical } \\
\text { Resistance to } \\
\text { Hot KOH; } \\
\mathrm{H}_{2} \mathrm{SO}_{4}{ }^{(\mathrm{b})}\end{array}$ \\
\hline \multicolumn{10}{|c|}{ Metals } \\
\hline $\begin{array}{l}\text { Nickel } \\
\text { Alstenitic }\end{array}$ & 8902 & 199.5 & $-/-$ & $403-462$ & $-/-$ & 13.3 & $\mathrm{n} / \mathrm{a}$ & $1.2 \times 10^{-10}$ & Good; fair \\
\hline $\begin{array}{c}\text { Austenitic } \\
\text { stainless steel } \\
\text { 316L }\end{array}$ & 8000 & $192-200$ & $-/-$ & $450-620$ & $-/-$ & 15.9 & $\mathrm{n} / \mathrm{a}$ & $0.7-1.2 \times 10^{-11}$ & Fair; fair \\
\hline Titanium & 4540 & 120.2 & 108.4 & 235 & $-/-$ & 8.35 & -- & $7 \times 10^{-16}$ & Poor; poor \\
\hline Ti-6Al-4V & 4420 & $106-114$ & $-1-$ & $-/-$ & 24 & 9.2 & $-/-$ & $-/$ & Fair; fair \\
\hline \multicolumn{10}{|c|}{ Ceramics } \\
\hline Quartz/silica & $2202-2650$ & 72.95 & $-/-$ & 69-276 & $-/-$ & 0.55 & $-/-$ & $-1-$ & Good; good \\
\hline $\begin{array}{l}\text { Soda lime/float } \\
\text { glass }\end{array}$ & 2530 & 72 & $-/-$ & $-/-$ & $-1-$ & 8.9 & $-/-$ & $-1-$ & Poor; good \\
\hline Borosilicate glass & 2510 & 82 & $-/-$ & $-/-$ & $-/-$ & $0.90-1.10$ & $-/-$ & $-/-$ & Poor; good \\
\hline $\begin{array}{c}\text { Sapphire } \\
\text { glass/fused } \mathrm{Al}_{2} \mathrm{O}_{3}\end{array}$ & 3980 & 379 & $-1-$ & -- & -4 & 8.3 & -- & $\sim 9 \times 10^{-17}$ & Good; good \\
\hline \multicolumn{10}{|c|}{ Thermoplastics } \\
\hline PMMA & $1180-1190$ & 3.03 & $2.55-3.17$ & 72.4 & $16-32$ & $34-77$ & $-40,50-90$ & $1.24 \times 10^{9}$ & Fair; fair \\
\hline PEEK & 1320 & $3.7-4.0$ & $-/-$ & $70-100$ & 85 & $26-108$ &,-- 250 & $0.36-1.2 \times 10^{9}$ & Good; good \\
\hline Polysulfone PSU & 1240 & 2.48 & 2.58 & $-/-$ & 69 & $31-51$ & $-/-,--$ & $-/-$ & Fair; fair \\
\hline PTFE & $2130-2220$ & $0.48-0.76$ & 0.41 & $10-40$ & 160 & $100-160$ & $-260,180-260$ & $3.3 \times 10^{9}$ & Good; good \\
\hline Polylactic acid & 1250 & $-/-$ & $-/-$ & $48.3-145$ & $12.8-29$ & Not given & $-/-$ & $-/-$ & $-/-;-/-$ \\
\hline \multicolumn{10}{|c|}{ Rubbers and elastomers } \\
\hline $\begin{array}{l}\text { EPDM Ethylene } \\
\text { propylene diene }\end{array}$ & 850 & $-/$ & $-/$ & 21 & $\mathrm{n} / \mathrm{a}$ & Not given & $-50,150$ & $17-14 \times 10^{9}$ & Good; -/- \\
\hline $\begin{array}{l}\text { Polysiloxanes } \\
\text { (silicones) }\end{array}$ & $-/-$ & - & $-/$ & 6.5 & $\mathrm{n} / \mathrm{a}$ & $-/-$ & $-60,232$ & - & Poor; poor \\
\hline $\begin{array}{l}\text { Fluoroelastomers } \\
\text { (e.g., Viton) }\end{array}$ & $1800-1860$ & $2.07-15.17$ & $-/$ & $4.8-11.0$ & $n / a$ & $-/$ & $-29,204$ & $3.5-7.3 \times 10^{9}$ & Fair; -/- \\
\hline
\end{tabular}


Table 2. Cont.

\begin{tabular}{|c|c|c|c|c|c|c|c|c|c|}
\hline Materials & $\begin{array}{l}\text { Density } \\
\left(\mathrm{kg} / \mathrm{m}^{-3}\right)\end{array}$ & $\begin{array}{l}\text { Elastic/Young's } \\
\text { Modulus } E \\
\text { (GPa) }\end{array}$ & $\begin{array}{l}\text { Compression/Bulk } \\
\text { Modulus, K (GPa) }\end{array}$ & $\begin{array}{c}\text { Ultimate } \\
\text { Tensile Stress } \\
\sigma_{\text {UTS }} \text { (MPA) }\end{array}$ & $\begin{array}{c}\text { Impact } \\
\text { Energy per } \\
\text { Unit Width } \\
(\mathrm{J} / \mathrm{m})^{(\mathrm{a})} \\
\end{array}$ & $\begin{array}{c}\text { Coefficient of } \\
\text { Linear Thermal } \\
\text { Expansion, } \alpha_{\mathrm{L}} \\
\left({ }^{\circ} 10^{-6} \mathrm{~K}^{-1}\right)\end{array}$ & $\begin{array}{c}\text { Min.- Max.- } \\
\text { Operating } \\
\text { Temperature } \\
\left({ }^{\circ} \mathrm{C}\right)\end{array}$ & $\begin{array}{c}\mathrm{H}_{2} \text { Permeability } \\
\text { (Mole } \mathrm{H}_{2} / \mathrm{m} \mathrm{s} \mathrm{MPa]} \\
\sim 300 \mathrm{~K}, 1 \mathrm{~Pa}\end{array}$ & $\begin{array}{c}\text { Chemical } \\
\text { Resistance to } \\
\text { Hot } \mathrm{KOH}^{(} ; \\
\mathrm{H}_{2} \mathrm{SO}_{4}(\mathbf{b}) \\
\end{array}$ \\
\hline \multicolumn{10}{|c|}{ Thermosets } \\
\hline Epoxy resin & $-/-$ & $-/-$ & $-/-$ & $-/-$ & $-/-$ & $200-260$ & $-/-$ & $\sim 0.57 \times 10^{9}$ & $-/-;-/-$ \\
\hline $\begin{array}{c}\text { LOCTITE }^{\circledR} \text { EA } \\
9483\end{array}$ & 1050-1110 & $2.1 \times 10^{-3}$ & $-1-$ & $-1-$ & -1 & $50-164$ & $-1-$ & - & Poor; poor \\
\hline $\begin{array}{c}\text { LOCTITE }^{\circledR} \text { EA } \\
9492\end{array}$ & & $6.7 \times 10^{-3}$ & $-1-$ & $-1-$ & $-1-$ & 63 & -1 & -1 & Fair;-/- \\
\hline $\begin{array}{c}\text { LOCTITE }^{\circledR} \text { Hysol } \\
\text { EA } 9460\end{array}$ & 1330 & $2.76 \times 10^{-3}$ & - & $-/$ & - & - & - & $-/$ & Poor; poor \\
\hline \multicolumn{10}{|c|}{ 3-D Printed polymers (c) } \\
\hline Fullcure RGD720 & $-/-$ & $2-3$ & $-/-$ & $55-60$ & $-/-$ & $-/-$ & $-/-$ & $-/-$ & $-/-;-/-$ \\
\hline $\begin{array}{l}\text { VeroClear, } \\
\text { RGD810; }\end{array}$ & $-/-$ & $2-3$ & $-/-$ & $50-65$ & $20-30$ & $-1-$ & $45-50$ & $-/-$ & Fair; -/- \\
\hline $\begin{array}{l}\text { Objet-RGD525-High- } \\
\text { Temperature-White }\end{array}$ & $-/-$ & $3.2-3.5$ & $-/-$ & $70-80$ & $14-16$ & $-/-$ & $\begin{array}{c}63-67 \text { after } \\
\text { post treatment } \\
75-80\end{array}$ & $-/-$ & Poor; -/- \\
\hline $\begin{array}{l}\text { VeroBlackPlus, } \\
\text { RGD875. }\end{array}$ & $-/-$ & 2.2 & $-/-$ & 51 & 24 & $-/$ & 43 & $-/$ & Fair; -/- \\
\hline
\end{tabular}

(a) For metals, Charpy V-notch impact (J). (b) Chemical resistance is taken for concentrated $\mathrm{KOH}$ and $20 \mathrm{wt} . \% \mathrm{H}_{2} \mathrm{SO}_{4}$, since these relate to the most commonly used electrolytes in alkaline and acidic conditions, respectively. (c) Properties for 3-D materials derived from manufacturer's Stratasys material data sheet [33], Chemical compatibility tested by the present authors by immersion test in stagnant $1.0 \mathrm{M} \mathrm{KOH}$ at $60^{\circ} \mathrm{C}$ for 7 days. 
Most designers of PEC device encasements borrow ideas from discrete electrolysers because of the close similarity in functionality. Metallic encasements are often used for discrete electrolysers because of their high mechanical strength, high temperature stability, high thermal conductivity and high electrical conductivity. Additionally, where weight should be kept to a minimum, such as for mobile applications or for siting on rooftops or integrating in building facades, metals may be undesirable. Typically, oxidation-resistant metals are required on the anode side, while materials resistance to hydrogen embrittlement are used on the cathode side. Austenitic stainless steel which have a relatively low carbon content, $18-25 \mathrm{wt} . \% \mathrm{Cr}$ and $8-20 \mathrm{wt} . \% \mathrm{Ni}$, in particular the AISI 316L grade (Fe-17Cr-12Ni-2.5 Mo) with a high corrosion resistance [35], could be a candidate material for PEC encasements.

Another option is titanium, because it is relatively lightweight, while maintaining sufficient mechanical strength for structural integrity. It also spontaneously forms a protective oxide preventing further deterioration under more positive potentials than that for oxygen evolution in water electrolysis, particularly in alkaline media. However, titanium when used on the cathode side is prone to hydrogen embrittlement, and although it forms a corrosion protective oxide layer as an anode, this may be undesirable if the casing is to provide electrical contact [38,39]. Moreover, titanium can potentially self-ignite under oxygen enrichment [40] and it is difficult to machine, making it relatively costly compared to stainless steel. These problems may be somewhat overcome by using titanium aluminium vanadium alloy Ti6Al4V, in which the aluminium increases the mechanical strength and decreases the weight of the alloy while the vanadium improves corrosion resistance [35]. Ti-6Al-4V also has a high fatigue strength with good tensile strength and creep resistance at temperatures typical of low temperature electrolysis. It is used to replace titanium, which easily oxidises to form a corrosion resistant passive film. Other metals commonly for structural components used such as aluminium, iron and copper are unsuitable for PEC devices chiefly because of the poor resistance to corrosion. Although nickel does not suffer from hydrogen embrittlement and is resistant to corrosion in alkaline solutions, dilute acids readily attack it [35]. Additionally, because of the relatively high cost, nickel is undesirable as an encasement material.

The EU Horizon 2020 funded NEXPEL project reported that, with the exception of platinum group metals and refractory metals and their alloys, which are costly, no other materials can provide both structural strength and corrosion resistance under high anodic bias in low $\mathrm{pH}$ conditions typical of proton exchange membranes (PEM) [40]. Thus, much research has been directed at finding protective coatings for steel as an alternative. A platinum-titanium bilayer was used to protect steel anode in a discrete PEM electrolyser from corrosion by electrolyte [41]; however, this would be costly to implement for large production volumes. The NEXPEL project consortium also tested a variety of protective coatings on stainless steel for resistance to degradation under high anodic bias in acidic conditions typical of PEM electrolysers [40]. They observed that with the exception of tantalum and platinum group metals, most materials such as nitrides of titanium and chromium, which from previous studies were predicted to be stable, failed to provide the required corrosion protection [40].

Polymers are organic composites made out of small molecular units that are crosslinked together either in an ordered or random way to form long chains. They are a versatile class of materials, which are generally low cost, easy to process and machine and have a reasonably high mechanical strength despite their very low weight, making them an interesting substitute for metals. They are typically grouped into thermoplastics and thermosets and occasionally, a third grouping called elastomers and rubbers may be categorised. The Young's Modulus of polymers increases from elastomers to glassy polymers to polymer crystals. Another important material property is the glass transition point, which dictates the maximum temperature at which polymers can be used for structural strength because it is an indicator of the softening of the material.

Thermoplastics are polymers that can be melted when heated then cooled down to a hardened form, almost indefinitely, without chemically changing. They can be easily formed into different shapes by compression moulding and injection moulding and thus are suitable for high volume automated 
production. They are generally electrically insulating but if necessary can be mixed with conductive fillers [42]. Thermoplastics such as acrylonitrile butadiene styrene (ABS) and polyvinyl chloride (PVC) are less interesting for PEC devices because of their low temperature stability, low chemical resistance and low mechanical strength.

Polystyrene has a relatively higher glass transition temperature of $100{ }^{\circ} \mathrm{C}$, but also has a low chemical resistance. Similarly, polycarbonate can be used between $-170{ }^{\circ} \mathrm{C}$ and $+121^{\circ} \mathrm{C}$, has a high impact resistance, but is not stable at high and low $\mathrm{pH}$ levels. PMMA and PLA have a high enough mechanical strength to provide structural support for PEC encasements; however, on hot summer days, the device temperature can reach and exceed $60^{\circ} \mathrm{C}$, the maximum allowed operating temperature. Thus, despite their attractiveness for prototyping, these materials are unsuitable for PEC devices targeting several years of service.

Although perfluoroalkoxy alkanes (PFA) and poly(tetrafluoroethylene) (PTFE) are stable in hot concentrated $\mathrm{KOH}$, they lack the mechanical stability required for withstanding high operating pressures of tens of bars [43] and impacts that are likely in outdoor operation. Thus, they are only suitable as compression sealing gaskets for hot alkaline conditions [44]. Additives can be used to tune the properties of a type of material within a certain limit; however, a compromise must be made between cost and added functionality. For example, relatively thick lower cost Teflon seals instead the more expensive Gylon, also PTFE based, despite its higher stability in hot alkaline conditions [44]. Fallisch et al. reported that chlorinated polyvinyl chloride as endplates led to non-uniform compression in a PEM electrolyser cell probably because of insufficient mechanical hardness [23]. Improvements in mechanical stability and distribution of compression force were realised by using a titanium anode endplate and either chlorinated polyvinyl chloride (CPVC) or polyphehylene sulfide (PPS) as the cathode endplate.

Thermosets are another type of polymers that do not melt when heated. They have a higher mechanical strength and better heat resistance than thermoplastics but tend to be more rigid. Most epoxy resins and glues used for PEC devices are thermosets. As already seen from the survey of PEC devices, epoxy resins are unlikely to be suitable for long-term durability of joint seals. Other groups also observed similar effects when using adhesives to fix separator in the casing of a discrete alkaline electrolyser because of complexity in implementation and difficulties in quality control [44]. One possible reason is that the manufacturers rarely disclose the phyisico-chemical properties of their products. Indeed, the epoxies seem to be used as a last resort because there is no suitable product on the market for adhesive sealing of PEC devices. The data sheets of the LOCTITE ${ }^{\circledR}$ EA9460, EA9492 and EA 9483 epoxies, which have been widely used as sealants for PEC devices as shown in Table 1, actually discourage their use in oxygen rich systems [45-47]. LOCTITE ${ }^{\circledR}$ EA 9492 has a slightly better chemical compatibility with aqueous environments than EA9460 and EA9483 but this is probably insufficient for prolonged service at extreme $\mathrm{pH}$ levels.

Rubbers and elastomers may be either thermoset or thermoplastic or a composite of both. They are polymers that can recover their shape almost immediately after a stretching load has been removed and are thus more suitable for edge sealing in PEC devices. Rubbers and elastomers are characterised by a glass transition temperature below $25^{\circ} \mathrm{C}$, a low Young's modulus and very high elongation at break, resulting in high flexibility. They are often used for sealing with compression by screws because of their softness. Care must be taken to operate elastomers below their maximum allowable temperature, as they may undergo irreversible chemical changes and lose their elasticity. Thus, most electrolysers stacks operating at high temperatures are made by a series of plates clamped together and sealed by compression of flat gaskets made of elastic chemically resistant material, e.g., polytetrafluoroethylene between two neighbouring plates [48].

Ceramics are generally brittle and have a low fracture toughness and thus are the least suited class of materials for load bearing applications. Glassy ceramics are attractive as the illumination window in PEC devices because of their high wear resistance and high optical transparency. However, they are more susceptible to thermal shock than metals or heat resistant plastics because of their combination 
of a lower thermal conductivity and higher brittleness. They are also difficult to fabricate but have a higher wear resistance than some metals and most polymers. Common ceramics that have been used for PEC devices are quartz and soda lime glass. Other alternatives could be borosilicate glass with a relatively higher thermal shock resistance than ordinary glass and sapphire glass, which is very hard. Ordinary glass may also be toughened by tempering or coating with tough protective layers.

The choice of materials for hermetic sealing of PEC devices must consider risks related to the nature of hydrogen and oxygen, fluctuations in temperature and internal pressure, and in some cases, corrosive electrolytes. Polymers are generally easy to machine, mould or print, moreover, they are lightweight and, in most cases, of low cost. However, the thermal mechanical properties of polymers are generally inferior to those of metals. Moreover, the $\mathrm{H}_{2}$ permeability of polymers increases with temperature and the effects of pressure are not yet understood [49]. Nevertheless, some polymers have excellent chemical compatibility in a wide range of $\mathrm{pH}$ in the range of operation for low temperature electrolysis. Additionally, the properties of final 3-D printed materials may differ from that of the base polymer depending on the density of the printed material, and post printing treatment. Also, the choice of polymer material for PEC encasement is not trivial because manufacturers put different additives to essentially the same material making comparisons difficult. Nevertheless, once a material with sufficient mechanical properties is identified, the next step is to check its stability in the expected $\mathrm{pH}$ of operation at the highest or typical expected temperature of operation of the PEC device. Figure 2 shows photographs of different candidate materials that we considered for use as components in a hermetically sealed PEC device encasement, before (left) and after a seven-day long immersion in $1.0 \mathrm{M} \mathrm{KOH}$ held at $60^{\circ} \mathrm{C}$.
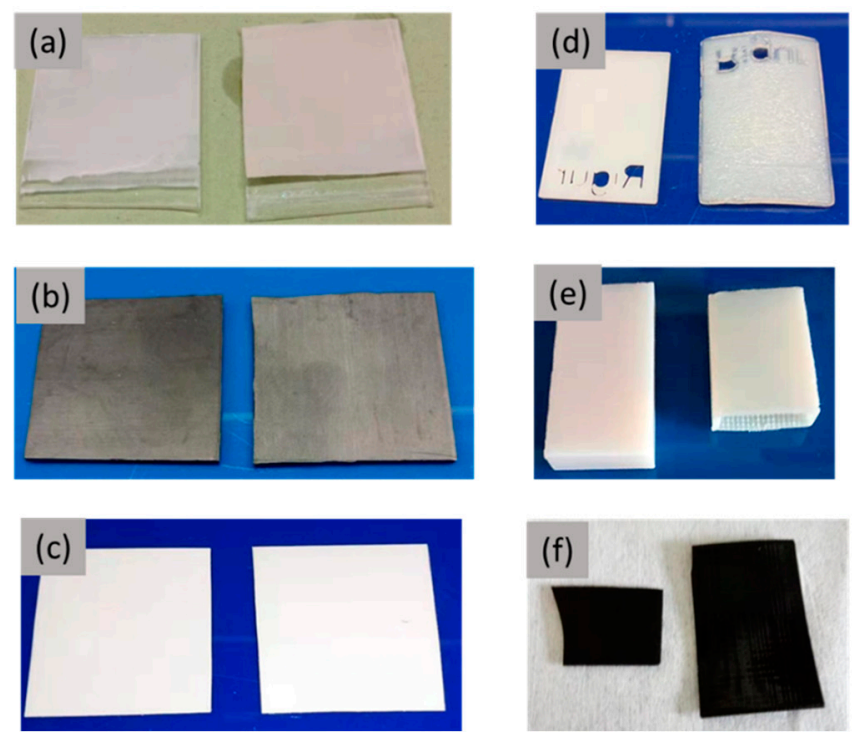
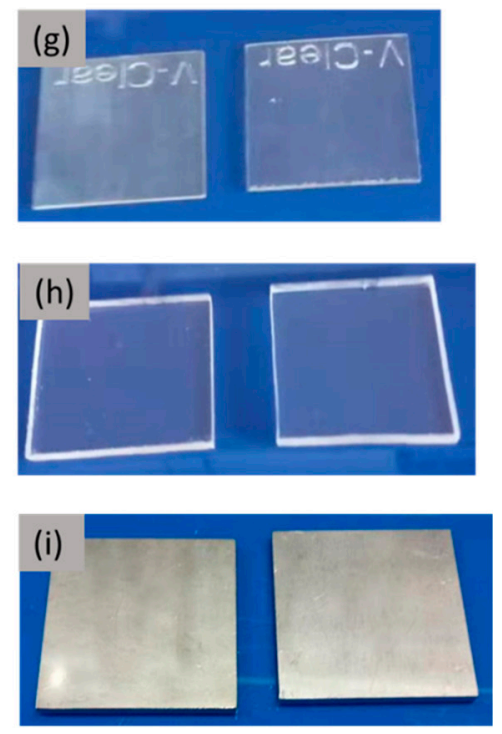

Figure 2. Photographic images showing the effect of immersion treatment, in $1.0 \mathrm{M} \mathrm{KOH}$ held at $60{ }^{\circ} \mathrm{C}$ for 7 days, on several sealing and encasement materials that could be used for PEC devices. The specimens are arranged with the initial state and the exposed state on the left and right, respectively. (a) LOCTITE ${ }^{\circledR}$ EA 9492 non-conductive adhesive on glass, (b) EPDM, (c) Coveme Tedlar Dymat ${ }^{\circledR}$ PV backsheet, (d) 3-D printed polypropylene based, Rigur, (e) Objet RGD525 HT, (f) VeroBlack, (g) 3-D printed PMMA derivative (VeroClear), (h) bulk PMMA (i) 316L stainless steel. The starting materials for all 3-D printed polymers in (d) to (g), inclusive, are manufactured by Stratasys.

The non-conductive adhesive, and most of the 3-D printed materials (Objet RGD525 High temperature white acrylic-based thermoplastic for high temperature application, Rigur polypropylene based; VeroBlack and VeroClear both PMMA derivatives) showed changes in appearance and can be deemed unsuitable at least for long service lifetime. On the hand, the bulk PMMA plate, the EPDMA piece and the PV backsheet, as well as the stainless steel, showed no visible change. The PV back 
sheet is in fact a laminate of different polymers namely Coveme Dymat ${ }^{\circledR}$ a polyester protected by Tedlar ${ }^{\circledR}$, a polyvinyl fluoride, with good outdoor wearing properties and probably benefits from a combination of the advantages of both materials. These observations on a centimetre length scale were also confirmed by closer inspection of the surface using the laser microscopy at $\times 20$ magnification. The resulting laser microscope images are presented in Figure 3, with the samples presented in the same order as was used for Figure 2. Significant the changes in the surface appearance were evident for the Loctite adhesive (Figure 3a), which was removed in some places, while the surfaces of the 3-D printed polymers Rigur (Figure 3d), RGD525 (Figure 3e) and VeroClear (Figure 3g) appeared to have roughened after the warm alkali exposure. The Veroblack (Figure 3f) showed evidence of a polishing effect whereby, the surface smoothened after the warm alkali exposure. In contrast, the microscopic appearance surfaces of the remaining materials remained unchanged.

(a)

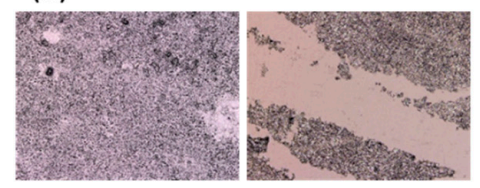

(b)

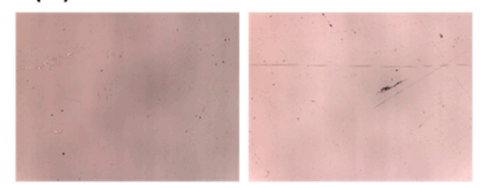

(c)

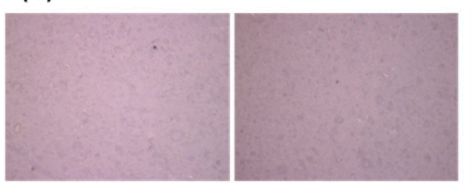

(d)

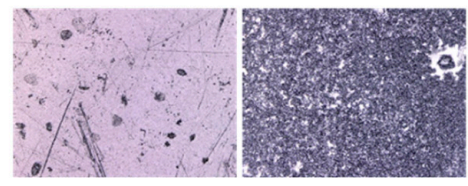

(e)

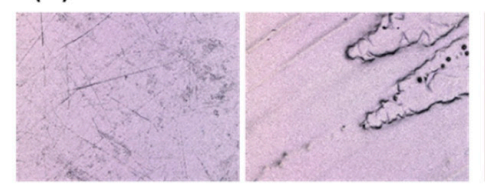

(f)

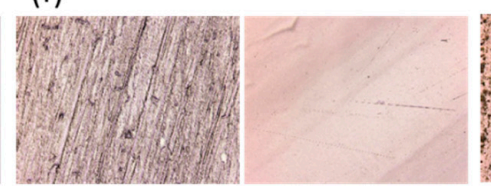

(g)

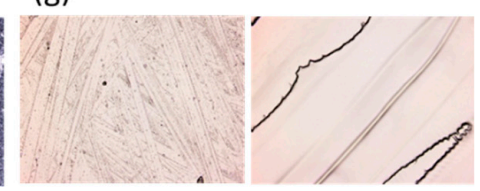

(h)

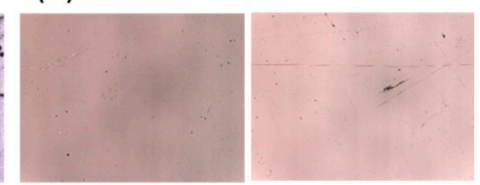

(i)

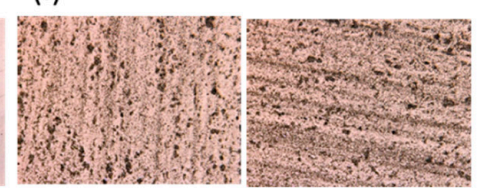

Figure 3. Laser microscope images with $\times 20$ magnification, showing the effect of immersion treatment, in $1.0 \mathrm{M} \mathrm{KOH}$ held at $60{ }^{\circ} \mathrm{C}$ for 7 days, on several sealing and encasement materials that could be used for PEC devices. The specimens are arranged with the initial state and the exposed state on the left and right, respectively. (a) LOCTITE ${ }^{\circledR}$ EA 9492 non-conductive adhesive on glass, (b) EPDM, (c) Coveme Tedlar Dymat ${ }^{\circledR}$ PV backsheet, (d) 3-D printed polypropylene based, Rigur, (e) Objet RGD525 HT, (f) VeroBlack, (g) 3-D printed PMMA derivative (VeroClear), (h) bulk PMMA (i) 316L stainless steel. The starting materials for all 3-D printed polymers in (d) to (g), inclusive, are manufactured by Stratasys.

In conclusion, none the materials commonly available on the market today are able to individually achieve all the requirements for hermetic sealing of PEC devices. Moreover, such materials are expected to have multiple functionalities, which may not be reconcilable with the related added cost of processing. Thus, the next section seeks to draw inspiration from synergies with photovoltaic devices as well as related electrochemical devices to address the challenge of hermetic sealing in PEC devices.

\section{Perspectives and Future Research Directions}

In order to develop hermetic seals that are suitable for operation of scaled up PEC devices, appropriate quality and safety tests should be developed to assess and predict the effectiveness of the sealing materials and techniques over the device service life. Such tests should consider the risks and hazards associated with operating the PEC devices in consideration of realistic operating conditions. In addition, research efforts using synergies borrowed from hermetic sealing approaches in related fields such as electrolysers, fuel cells and batteries should be channelled to solving the current materials and technical challenges for hermetic sealing of PEC devices. 


\subsection{Possible Qualification and Safety Tests}

PV modules are expected to endure various environmental conditions, while ensuring mechanical stability as well as low moisture ingress. The IEC 61730-2:2016 standard lays down the testing sequence intended to verify that the photovoltaic (PV) module has been constructed in such a way as to prevent electrical shock, fire hazards and personal injury due to mechanical and environmental stresses during operation [50]. Furthermore, quality tests are used to assess the reliability of the different types of photovoltaic cells on the market according to the following standards namely, IEC 61215 for c-Si, IEC 61646 for thin film and IEC 62108 for CPV [50]. It is inevitable that these standards have to be adapted to PEC devices to account for the presence of possibly corrosive, liquid electrolyte and explosive product gases. Nevertheless, we can identify some synergies with PEC cells. Table 3 summarises possible failure modes in PEC devices, their causes and potentially relevant tests used to qualify the safety and reliability of photovoltaic modules and electrolysers (and fuel cells). These tests provide an indication of tests that could be relevant for PEC devices and would naturally have to be adapted to be effective for the special case.

Table 3. Possible failure modes in PEC devices, their causes and possible qualification tests.

\begin{tabular}{|c|c|c|c|c|}
\hline Failure & Cause/Stress Factors & Implication & Possible PV Test & $\begin{array}{c}\text { Possible } \\
\text { Electrolyser and } \\
\text { Fuel Cell Test }\end{array}$ \\
\hline $\begin{array}{l}\text { (Electro-chemical, } \\
\text { photo) corrosion }\end{array}$ & $\begin{array}{c}\mathrm{pH} \text {, temperature } \\
\text { extremes, temperature } \\
\text { cycling, bias potential }\end{array}$ & $\begin{array}{l}\text { Possible mechanical } \\
\text { failure, contamination }\end{array}$ & $\begin{array}{l}\text { Dry heat conditioning, } \\
\text { ultra- violet radiation } \\
\text { (UV) testing, damp } \\
\text { heat, outdoor exposure }\end{array}$ & Corrosion test \\
\hline Device fracture & $\begin{array}{c}\text { Explosion, over } \\
\text { pressure, temperature } \\
\text { shocks, mechanical } \\
\text { impact, temperature } \\
\text { and/or pressure } \\
\text { fluctuations }\end{array}$ & $\begin{array}{l}\text { Catastrophic structural } \\
\text { failure of encasement, } \\
\text { broken electrical } \\
\text { interconnects, } \\
\text { photo-absorber cells, } \\
\text { windows }\end{array}$ & $\begin{array}{c}\text { Hail test, Module } \\
\text { breakage test, long } \\
\text { term outdoor exposure }\end{array}$ & Pressure drop test \\
\hline Fatigue cracking & $\begin{array}{c}\text { Temperature and/or } \\
\text { pressure cycling, } \\
\text { mechanical stress, } \\
\text { extended UV exposure, } \\
\text { hydrogen } \\
\text { embrittlement, } \\
\text { oxidation }\end{array}$ & $\begin{array}{c}\text { Cracked } \\
\text { photo-absorbers, } \\
\text { substrates or encasement, } \\
\text { delaminated coatings, } \\
\text { broken interconnects, } \\
\text { sealing joints and front } \\
\text { window }\end{array}$ & $\begin{array}{l}\text { Dynamic mechanical } \\
\text { loading; damp heat; } \\
\text { freeze-thaw cycling, } \\
\text { hail test; outdoor } \\
\text { exposure, cold and/or } \\
\text { dry heat conditioning }\end{array}$ & $\begin{array}{l}\text { Vibration test, } \\
\text { temperature and/or } \\
\text { pressure cycling, }\end{array}$ \\
\hline $\begin{array}{l}\text { Distortion or } \\
\text { deformation }\end{array}$ & $\begin{array}{c}\text { Over pressure, } \\
\text { over-heating, fire }\end{array}$ & $\begin{array}{l}\text { Catastrophic failure of } \\
\text { entire device; leaks }\end{array}$ & $\begin{array}{l}\text { Ignitability test if } \\
\text { polymeric materials } \\
\text { are used }\end{array}$ & Pressure drop test \\
\hline Sealing joint failure & $\begin{array}{c}\text { Delamination of } \\
\text { adhesive at joints, } \\
\text { temperature and/or } \\
\text { pressure cycling, } \\
\text { mechanical stress; } \\
\text { corrosion and } \\
\text { penetration of moisture }\end{array}$ & $\begin{array}{l}\text { Loss of adhesion of } \\
\text { epoxies and glues if } \\
\text { used, delamination of } \\
\text { functional coatings }\end{array}$ & $\begin{array}{l}\text { Humidity freeze, } \\
\text { outdoor exposure, peel } \\
\text { test for cemented joints, } \\
\text { lap shear strength test, } \\
\text { materials creep test }\end{array}$ & $\begin{array}{c}\text { Damp } \\
\text { heat;pressure drop } \\
\text { test }\end{array}$ \\
\hline Ground faults & Wet leakage current & $\begin{array}{l}\text { Electrical shock, } \\
\text { increased risk of fire } \\
\text { and/or explosion }\end{array}$ & $\begin{array}{c}\text { Damp heat; ignitability } \\
\text { test if polymeric } \\
\text { materials are used }\end{array}$ & $\begin{array}{l}\text { Dry and wet } \\
\text { insulation } \\
\text { resistance }\end{array}$ \\
\hline
\end{tabular}

Leak tightness of the electrolyser component can be tested at $150 \%$ of the operating pressure of the design [44]. As an extra safety measure, the balance of plant in PEC should be designed to avoid leakages and to stop operation once a leakage of $\mathrm{H}_{2}, \mathrm{O}_{2}$ and/or electrolyte, above a certain threshold, is sensed. 


\subsection{Lessons from Related Electrochemical Devices}

The casing materials and sealing techniques used for related electrochemical devices such as discrete electrolysers, fuels cells and flow batteries, that have been successfully commercialised may inform developments in hermetic sealing of PEC devices.

Similar to PEC devices, there have been numerous reports on laboratory sized 3-D printed polymer electrolysers. In order to improve the electrical conductivity, 3-D printed polypropylene flow plates used for a discrete PEM electrolyser were sputtered coated with silver [51]. The silver coating on the anode side was additionally plated with gold to prevent attack by oxidation. The stack was sealed with PTFE gaskets on anode side via bolt compression using $7.5 \mathrm{Nm}$ [51]. Although a durability test was performed, degradation was not attributed to failure of sealing, since only the device voltage was monitored. Similarly, to most PEC devices, the conventional technique for edge sealing in PEM fuel cells is by compressing a sealing gasket between the end plates but more elaborate arrangements involving multiple seals are possible [as described for example, in 52]. Therein, flow processable sealing materials and/or thermosetting liquid injection mouldable compounds are used in addition to flat gaskets to ensure better sealing. While flow processable elastomers such as silicone are easily compressible making them desirable seals, they are not stable in the oxidative and reducing environment of fuels cells and electrolysers. In WO2016130781, a second seal made out of thermal plastic material is used to shield the elastomer from the active part of the fuel cell [52].

Chen et al. identified the causes of failure modes in fuel cells among which leakage was deemed to be significant [53]. They suggested a suite of tests to ensure leak-free fuel cells composed of static and dynamic stress scans (with loading and or temperature varied) on single components i.e., bipolar plates, end plates, sealing gaskets and complete stacks. Based on these findings, they developed a leak test method that could be performed at different stages during assembly of the fuel cell stack. Of particular relevance to the encasement was the pressure decay test, which was also introduced at different stages (compression, bolting, break-in, performance test) of the stack assembly in a so-called stack quality characterization system. More comprehensive tests for leakage have been developed for solid oxide-fuel cells and -electrolysers, perhaps because they are designed to work at more extreme conditions. Lin et al. described a series of sealing integrity tests that could be adapted to PEC devices including pressure drop test as a function of temperature and rapture test [54]. A further development is a set of tests specifically targeted at the sealing of joints between two dissimilar materials in which the mechanical strength was tested in both reducing and oxidizing environment and also subjected to thermal aging albeit at very high temperatures of $800{ }^{\circ} \mathrm{C}$ [54].

Further insights for hermetic sealing of PEC devices especially for alkaline conditions can be drawn from battery technology. Nickel and nickel iron alloy coated stainless steel have been used as the casing material for alkaline batteries with $20-30 \mathrm{wt} . \% \mathrm{KOH}$ aqueous solution as an electrolyte [55] and have been tested in alkaline electrolysers operating at $80^{\circ} \mathrm{C}$ and 20 bar [56]. Sealing techniques used for redox flow batteries may prove useful for alkaline PEC devices, whereby the epoxies are in some cases applied by multistep solid casting to create a continuous piece of material, thus minimizing voids [57]. Alternatively, fusion bonding by heat or solvent can be used to fuse the frame and bipolar plates to create an edge seal [58]. Yet, another option is moulding the casing into one piece to minimise the number of joints in the set-up.

\section{Discussion}

Several issues have to be considered when ensuring hermetic sealing of scaled up PEC devices for safe and reliable operation. Firstly, because the PEC device is expected to operate in outdoor conditions where temperature fluctuations occur, the matching of the coefficient of linear expansion of the materials used for the casing including any seals or adhesives is important. Generally, materials with high thermal expansion coefficients are not desirable because they are more susceptible to breakage under stress caused by thermal cycling. Secondly, to ensure sufficient structural integrity, the materials used must have a high degree of elasticity to resist deformation after expansion but at the same time be 
rigid enough not to buckle under compressive force. Furthermore, in order to withstand high shock impact, they should be relatively tough to avoid fracture. Thirdly, the materials must be chemically compatible with both the electrolyte and the product gases under all possible operating conditions to ensure structural integrity over the required service life of the PEC device. Fourthly, for economic reasons, the materials and sealing techniques used should be of low cost and simple to adapt to manufacturing in large volumes.

From our review of the literature on fully functional PEC prototypes, it is evident that there is no consensus yet on which encasement materials and sealing techniques are best suited for hermetic sealing of PEC devices. Although PMMA is often used for PEC device encasement, the device temperature during solar hydrogen generation can reach $60{ }^{\circ} \mathrm{C}$ in summer months. This value is close to the maximum allowable operating temperature of PMMA, and thus, such devices are unlikely to have a service lifetime of several years.

While metals may be attractive from the thermal-mechanical point of view, their high mass density, relatively high cost and limited chemical compatibility, may limit their adaptation as encasement materials. On the other hand, chemically stable polymers are likely to lack the thermal mechanical properties required for structural integrity, which becomes crucial as the device size increases. Moreover, when selecting materials, one should note that the available values of physico-chemical properties can only be used as a starting point since they are usually determined under a specific operating condition. One can expect that a combination of different levels of temperature, pressure, $\mathrm{pH}$, velocity flow rates and mechanical loading conditions would have either a cumulative or an exponential effect on the failure rates of the casing or sealing material.

Since a window is required to illuminate the PEC device and, in most cases, protect the photo-absorber from the elements, it is inevitable that part of the PEC encapsulation shall consist of glassy materials. However, glassy materials lack the flexibility that is required to withstand the temperature and pressure fluctuations that would follow intermittent diurnal weather conditions. Additionally, since at least two different materials have to be joined together either by adhesive bonding or by compressive clamping, this combination of different materials raises the need to carefully identify and select appropriate materials that fulfil specific functions, e.g., windows, mechanical support and sealing, while also fulfilling the global functionality of the entire encasement structure.

Several solutions may be used to ensure hermetic sealing in the absence of a material that can cover all the requirements for PEC device encasement. One could consider using anti-corrosion coatings or even polymeric linings to protect the internal walls of the encasement, thus allowing the use of low cost but structurally strong materials for the PEC encasement. Nickel and nickel alloys would also be more cost-effective protective coatings for stainless steel than noble metals for both acidic and alkaline PEC devices [35]. Again, the thermal expansion coefficient of the coating and substrate metal must be matched to avoid breaching of the protective coating because of damage from thermal cycling. The PEC device could also be composed of extremely low-cost materials with replacement planned after a fixed number of service hours. For instance, the electrolyser component could be housed in a polymeric pouch that is glued to the rigid illumination window and mechanically supported by low cost, braces made from lightweight metal such as aluminium. As we showed in this contribution, laminates of polymers such as those used for PV back-sheets might be an interesting starting option for pouch like encasement of the PEC device because of the high degree of engineering aimed at a service lifetime $\sim 20$ years in outdoor conditions. The use of multiple step sealing or minimizing the length of joints by constructing the encasement out of one piece for example by moulding could reduce the risk of leakage at the edge and joints between two different materials. Other options include changing the operating conditions of the PEC device, for example, working at close to neutral $\mathrm{pH}[19,21,28,29]$ and replacing flowing liquid with moist air [59]. We note here that for the special case of solar driven hydrogen production, options like limiting effects of temperature fluctuations are not possible because of the intermittent nature of solar irradiation. 
Lastly, since a plurality of material properties and operating conditions have to be considered when engineering the hermetic sealing of PEC devices, computations may be useful in making material choices. Numerical modelling of the fluid and thermal dynamics as well as mechanical loading conditions at the design stage may aid prediction of stress development and/or distributions later in the device lifetime. Additionally, Bayesian statistical methods could be used to predict the probability of failure thus aiding the identification appropriate combinations of materials for hermetic sealing of PEC devices. This could move the current state of development of PEC devices away from experimental trial and error to simulation aided design predictions thus accelerating the development towards commercial ready devices or systems.

\section{Conclusions}

This review presented the state of the art of hermetic sealing used for PEC water splitting laboratory prototypes and demonstrators. We appraised the material choices and sealing techniques used for contemporary PEC devices in terms of their suitability for hermetic sealing of scaled- up devices and found these lacking due to several factors. First, there is the absence of suitable casing and epoxy materials on the market, which combine chemical compatibility with the reactants and products of water electrolysis with the appropriate set of mechanical properties for structural support and joint sealing, respectively. Moreover, in addition to a lack of suitable epoxy adhesives, compression sealing which though successful in discrete electrolysers and fuel cells is challenging in PEC devices because of the requirement for a transparent window, which is always a brittle glassy material. To overcome these problems, this study proposes a range of recommendations to accelerate the development of hermetic seals for PEC devices based on synergies with related devices that have already been commercialised. We conclude by noting that the discussions in this review are not exclusive to hermetic sealing of PEC devices for solar water splitting but can be extended to other emerging solar driven electrolysis devices such as those being developed to split nitrogen and carbon dioxide to create ammonia and organic fuel carriers, respectively.

Author Contributions: S.C. designed and guided the study and wrote the paper; S.C., S.A. and E.K. collected literature reviewed literature and compiled some of the data used; S.A., E.K., F.B. and I.D. carried out experiments and analysed the data; S.C. and R.S. acquired the funds that supported the work in this paper.

Funding: This research was done under the PECSYS project. The project has received funding from the FUEL CELLS AND HYDROGEN 2 JOINT UNDERTAKING under grant agreement No 735218. This Joint Undertaking receives support from the EUROPEAN UNION'S HORIZON 2020 RESEARCH AND INNOVATION programme and Hydrogen Europe and N.ERGHY. The project started on the 1st of January 2017 with a duration of 48 months.

Acknowledgments: We are grateful to Bernd Stannowski and Stefan Janke of the Silicon Photovoltaics Group at Helmholtz Zentrum Berlin for providing the silicon heterojunction mini-modules. Jannick Preiß is thanked for assistance with PEC device measurements. AGFA NV is gratefully acknowledged for providing the Zirfon separation membranes used to realise the PEC devices. We thank the various authors and institutions that provided images of their devices without charge namely, F. Finger and J. Becker of Forschungszentrum Jülich, Germany; Virgil Andrei of University of Cambridge, UK; Sophia Hausenner of Ecole Polytechnique Federale de Lausanne, Switzerland; Tânia Lopes of University of Porto, Portugal and Michael Schwarze of Technical University Berlin, Germany. Note that permission to reuse the courtesy images and figures in any form must be obtained directly from the rightful copyright owners.

Conflicts of Interest: The authors declare no conflict of interest. The funders had no role in the design of the study; in the collection, analyses or interpretation of data; in the writing of the manuscript, or in the decision to publish the results.

\section{References}

1. Rongé, J.; Bosserez, T.; Martel, D.; Nervi, C.; Boarino, L.; Taulelle, F.; Decher, G.; Bordiga, S.; Martens, J.A. Monolithic cells for solar fuels. Chem. Soc. Rev. 2014, 43, 7963-7981. [CrossRef]

2. Xiang, C.; Weber, A.Z.; Ardo, S.; Berger, A. Modeling, simulation, and implementation of solar-driven water-splitting devices. Angew. Chem. Int. Ed. 2016, 55, 12974-12988. [CrossRef] 
3. Bosserez, T.; Rongé, J.; van Humbeeck, J.; Haussener, S.; Martens, J. Design of compact photoelectrochemical cells for water splitting. Oil Gas Sci. Technol. Rev. IFP Energies Nouv. 2015, 70, 791-902. [CrossRef]

4. Hu, S.; Lewis, N.S.; Ager, J.W.; Yang, J.; McKone, J.R.; Strandwitz, N.C. Thin-film materials for the protection of semiconducting photoelectrodes in solar-fuel generators. J. Phys. Chem. C 2015, 119, 24201-24228. [CrossRef]

5. Nandjou, F.; Haussener, S. Degradation in photoelectrochemical devices: Review with an illustrative case study. J. Phys. D Appl. Phys. 2017, 50, 124002. [CrossRef]

6. Ager, J.W.; Shaner, M.R.; Walczak, K.A.; Sharp, I.D.; Ardo, S. Experimental demonstrations of spontaneous, solar-driven photoelectrochemical water splitting. Energy Environ. Sci. 2015, 8, 2811-2824. [CrossRef]

7. Kim, J.H.; Hansora, D.; Sharma, P.; Jang, J.-W.; Lee, J.S. Toward practical solar hydrogen production-An artificial photosynthetic leaf-to-farm challenge. Chem. Soc. Rev. 2019, 48, 1908-1971. [CrossRef]

8. Ardo, S.; Rivas, D.F.; Modestino, M.A.; Greiving, V.S.; Abdi, F.F.; Llado, E.A.; Artero, V.; Ayers, K.; Battaglia, C.; Becker, J.P.; et al. Pathways to electrochemical solar-hydrogen technologies. Energy Environ. Sci. 2018, 11, 2768-2783. [CrossRef]

9. Bard, A.J.; Memming, R.; Miller, B. Terminology in Semiconductor Electrochemistry and Photoelectrochemical Energy-Conversion-(Recommendations 1991). Pure Appl. Chem. 1991, 63, 569-596. [CrossRef]

10. Beeson, H.; Woods, S. Guide for Hydrogen Hazards Analysis on Components and Systems, NASA Technical Memorandum, NASMTM-2003-212059. 2003. Available online: https:/ntrs.nasa.gov/archive/nasa/casi.ntrs. nasa.gov/20040033949.pdf (accessed on 6 September 2019).

11. European Industrial Gases Association. EIGA Doc. 04, Fire Hazards of Oxygen and Oxygen Enriched Atmospheres. 2018. Available online: https://www.eiga.eu/index.php?eID=dumpFile\&t=f\&f=3371\&token= a378faf4d18ff8a6d1c208a4a3d32bce1d47f6bc (accessed on 6 September 2019).

12. Sathre, R.; Scown, C.D.; Morrow, W.R.; Stevens, J.C.; Sharp, I.D.; Ager, J.W.; Walczak, K.; Houle, F.A.; Greenblatt, J.B. Life-cycle net energy assessment of large-scale hydrogen production via photoelectrochemical water splitting. Energy Environ. Sci. 2014, 7, 3264. [CrossRef]

13. ISO. ISO 22734-1:2008 Hydrogen Generators Using Water Electrolysis Process-Part 1: Industrial and Commercial Applications; ISO: Geneva, Switzerland, 2008.

14. ISO. ISO 22734-2:2011, Hydrogen Generators Using Water Electrolysis Process-Part 2: Residential Applications; ISO: Geneva, Switzerland, 2008.

15. Shroeder, V.; Emonts, B.; Janßen, H.; Schulze, H.-P. Explosion limits of hydrogen-oxygen mixtures at initial pressures up to 200 bar. Chem. Eng. Technol. 2004, 27, 847-851. [CrossRef]

16. Conrad, D.; Kaulbars, R. Druckabhaengigkeit der Explosionsgrenzen von Wasserstoff. Chem. Ing. Tech. 1995, 67, 185-188. [CrossRef]

17. Ritchie, R.O. The conflicts between strength and toughness. Nat. Mater. 2011, 10, 817-822. [CrossRef] [PubMed]

18. Becker, J.-P.; Turan, B.; Smirnov, V.; Welter, K.; Urbain, F.; Wolff, J.; Haas, S.; Finger, F. A modular device for large area integrated photoelectrochemical water-splitting as a versatile tool to evaluate photoabsorbers and catalysts. J. Mater. Chem. A 2017, 5, 4818. [CrossRef]

19. Andrei, V.; Hoye, R.L.Z.; Crespo-Quesada, M.; Bajada, M.; Ahmad, S.; De Volder, M.; Friend, R.; Reisner, E. Scalable triple cation mixed halide perovskite-bivo4 tandems for bias-free water splitting. Adv. Energy Mater. 2018, 8, 1801403. [CrossRef]

20. Vilanova, A.; Lopes, T.; Spenke, C.; Wullenkord, M.; Mendes, A. Optimized photoelectrochemical tandem cell for solar water splitting. Energy Storage Mater. 2018, 13, 175-188. [CrossRef]

21. Tembhurne, S.; Nandjou, F.; Haussener, S. A thermally synergistic photo-electrochemical hydrogen generator operating under concentrated solar irradiation. Nat. Energy 2019, 4, 399-407. [CrossRef]

22. Schröder, M.; Kailasam, K.; Borgmeyer, J.; Neumann, M.; Thomas, A.; Schomäcker, R.; Schwarze, M. Hydrogen evolution reaction in a large-scale reactor using a carbon nitride photocatalyst under natural sunlight irradiation. Energy Technol. 2015, 3, 1014-1017. [CrossRef]

23. Fallisch, A.; Schellhase, L.; Fresko, J.; Zedda, M.; Ohlmann, J.; Steiner, M.; Boesch, A.; Zielke, L.; Thiele, S.; Dimroth, F.; et al. Hydrogen concentrator demonstrator module with $19.8 \%$ solar-to-hydrogen conversion efficiency according to the higher heating value. Int. J. Hydrogen Energy 2017, 42, 26804-26815. [CrossRef] 
24. Verlage, E.; Shu, H.; Liu, R.; Jones, R.J.R.; Sun, K.; Xiang, C.; Lewis, N.S.; Atwater, H.A. A monolithically integrated, intrinsically safe, $10 \%$ efficient, solar-driven water-splitting system based on active, stable earth-abundant electrocatalysts in conjunction with tandem III-V light absorbers protected by amorphous $\mathrm{TiO}_{2}$ films. Energy Environ. Sci. 2015, 8, 3166-3172. [CrossRef]

25. Walczak, K.; Chen, Y.; Karp, C.; Beeman, J.W.; Shaner, M.; Spurgeon, J.; Sharp, I.D.; Amashukeli, X.; West, W.; Jin, J.; et al. Modeling, simulation, and fabrication of a fully integrated, acid-stable, scalable solar-driven water-splitting system. ChemSusChem 2015, 8, 544-551. [CrossRef] [PubMed]

26. Walczak, K.A.; Segev, G.; Larson, D.M.; Beeman, J.W.; Houle, F.A.; Sharp, I.D. Hybrid composite coatings for durable and efficient solar hydrogen generation under diverse operating conditions. Adv. Energy Mater. 2017, 7, 1602791. [CrossRef]

27. Kistler, T.A.; Danilovic, N.; Agbo, P. A monolithic photoelectrochemical device evolving hydrogen in pure water. J. Electrochem. Soc. 2019, 166, H656-H661. [CrossRef]

28. Modestino, M.A.; Walczak, K.A.; Berger, A.; Evans, C.M.; Haussener, S.; Koval, C.; Newman, J.S.; Ager, J.W.; Segalman, R.A. Robust production of purified $\mathrm{H}_{2}$ in a stable, self-regulating, and continuously operating solar fuel generator. Energy Environ. Sci. 2014, 7, 297-301. [CrossRef]

29. Wullenkord, M.; Spenke, C.; Vilanova, A.; Lopes, T.; Mendes, A. Public report on performance of the large-area prototype array, Project Deliverable Report—D6.4, Photoelectrochemical Demonstrator Device for Solar Hydrogen Generation (PECDEMO). 2017. Available online: https://archiveweb.epfl.ch/pecdemo.epfl.ch/files/ content/sites/pecdemo/files/public\%20files/PECDEMO\%20Deliverable\%206.4_DLR_UPorto.pdf (accessed on 30 September 2019).

30. Bicer, Y. Investigation of Novel Ammonia Production Options Using Photoelectrochemcial Hydrogen. Ph.D. Thesis, University of Ontario, Oshawa, ON, Canada, 2017. Available online: https:/ir.library.dc-uoit.ca/ bitstream/10155/780/1/Bicer_Yusuf.pdf (accessed on 30 September 2019).

31. Goto, Y.; Hisatomi, T.; Wang, Q.; Higashi, T.; Ishikiriyama, K.; Maeda, T.; Sakata, Y.; Oku, S.; Tokudome, H.; Katayama, M.; et al. A particulate photocatalyst water-splitting panel for large-scale solar hydrogen generation. Joule 2018, 2, 509-520. [CrossRef]

32. Tolod, K.R.; Hernández, S.; Russo, N. Recent Advances in the $\mathrm{BiVO}_{4}$ Photocatalyst for Sun-Driven Water Oxidation: Top-Performing Photoanodes and Scale-Up Challenges. Catalysts 2017, 7, 13. [CrossRef]

33. Available online: https://www.stratasys.com/materials/search/ (accessed on 28 August 2019).

34. Welter, K.; Hamzelui, N.; Smirnov, V.; Becker, J.-P.; Jaegermann, W.; Finger, F. Catalysts from earth abundant materials in a scalable, stand-alone photovoltaic electrochemical module for solar water splitting. J. Mater. Chem. A 2018, 6, 15968-15976. [CrossRef]

35. Cardarelli, F. Materials Handbook, A concise Desktop Reference, 2nd ed.; Springer Verlag: London, UK, 2008.

36. Henager, C.H. Hydrogen Permeation Barrier Coatings, Materials for the Hydrogen Economy; Jones, R.H., Thomas, G.J., Eds.; CRC Press: Boca Raton, FL, USA, 2007; Chapter 8; pp. 181-190.

37. Barth, R.R.; Simmons, K.L.; San Marchi, C. Polymers for Hydrogen Infrastructure and Vehicle Fuel Systems: Applications, Properties and Gap Analysis; Sandia Report; Sandia National Laboratories: Alberquerque, New Mexico; Livermore, CA, USA, October 2013; SAND2013-8904. Available online: https://prod-ng.sandia.gov/ techlib-noauth/access-control.cgi/2013/138904.pdf (accessed on 18 September 2019).

38. Jung, H.Y.; Huang, S.Y.; Popov, B.N. High-durability titanium bipolar plate modified by electrochemical deposition of platinum for unitized regenerative fuel cell (URFC). J. Power Sour. 2010, 195, 1950-1956. [CrossRef]

39. Kuromoto, N.K.; Simao, R.A.; Soares, G.A. Titanium oxide films produced on commercially pure titanium by anodic oxidation with different voltages. Mater. Charact. 2007, 58, 114-121. [CrossRef]

40. Kongstein, O.E.; Guillet, N.; Ødegård, A. WP5 "Porous Current Collectors and Materials for Bipolar Plate", Bibliographic Review. NEXPEL Project, Next-Generation PEM Electrolyzer for Sustainable Hydrogen Production. 2010. Available online: https:/www.sintef.no/globalassets/project/nexpel/pdf/nexpelwp5bibliographicreview--rt-deht-dr10-051-final.pdf (accessed on 26 July 2019).

41. Lettenmeier, P.; Wang, R.; Abouatallah, R.; Burggraf, F.; Gago, A.S.; Friedrich, K.A. Coated stainless steel bipolar plates for proton exchange membrane electrolyzers. J. Electrochem. Soc. 2016, 163, F3119-F3124. [CrossRef] 
42. Yeetsorn, R.; Fowler, M.W.; Tzoganakis, C. A Review of Thermoplastic Composites for Bipolar Plate Materials in PEM Fuel Cells, Nanocomposites with Unique Properties and Applications in Medicine and Industry; Cuppoletti, J., Ed.; Intech Open: Rijeka, Croatia, 2011; Available online: https: //www.intechopen.com/books/nanocomposites-with-unique-properties-and-applications-in-medicineand-industry/a-review-of-thermoplastic-composites-for-bipolar-plate-materials-in-pem-fuel-cells (accessed on 8 September 2019). [CrossRef]

43. Yde, L.; Kjartansdóttir, C.K.; Allebrod, F.; Mogensen, M.B.; Møller, P.; Hilbert, L.R.; Nielsen, P.T.; Mathiesen, T.; Jensen, J.; Andersen, L.; et al. Generation Alkaline Electrolysis, 2nd ed.; Final report; Århus University Business and Social Science-Centre for Energy Technologies: Aarhus, Denmark, 2013.

44. Hydrogen from RES: Pressurised Alkaline Electrolyser with High Efficiency and Wide Operating Range, RESelyser, Final Project Report. 2015. Available online: http://www.reselyser.eu/resources/RESelyser_final_ publishable_290615.pdf (accessed on 10 September 2019).

45. Henkel. LOCTITE EA 9460, Technical Data Sheet. December 2013. Available online: https: //tdsna.henkel.com/americas/na/adhesives/hnauttds.nsf/web/E26C4A5F8C916DE2882571870000DB25/ \$File/EA\%209460-EN.pdf (accessed on 30 September 2019).

46. Henkel. LOCTITE EA 9492; Technical Data Sheet; Henkel: Düsseldorf, Germany, 2014.

47. Henkel. LOCTITE EA 9483; Technical Data Sheet; Henkel: Düsseldorf, Germany, 2008.

48. James, T.H.; Michael, C.S. Electrolyser and Components Therefor. U.S. Patent 8,057,646B2, 15 November 2011.

49. Marchi, C.S. Nonmetals: Polymers (code 8100). In Technical Reference on Hydrogen Compatibility of Materials; Marchi, C.S., Somerday, B.P., Eds.; Sandia National Laboratories: Livermore, CA, USA, 2008. Available online: http://www.ca.sandia.gov/matlsTechRef/ (accessed on 10 September 2019).

50. Dunlop, E.D.; Gracia Amillo, A.; Salis, E.; Sample, T.; Taylor, N. Standards for the Assessment of the Environmental Performance of Photovoltaic Modules, Power Conditioning Components and Photovoltaic Systems; EUR 29247 EN.; Publications Office of the European Union: Luxembourg, 2018; ISBN 978-92-79-86608-1. [CrossRef]

51. Chisholm, G.; Kitson, P.J.; Kirkaldy, N.D.; Bloor, L.G.; Cronin, L. 3D printed flow plates for the electrolysis of water: An economic and adaptable approach to device manufacture. Energy Environ. Sci. 2014, 7, 3026-3032. [CrossRef]

52. Stewart, I.; Mcgowan, D.; Gallagher, E. Seal for Solid Polymer Electrolyte Fuel Cell. Patent WO201613078118, 18 August 2016.

53. Chen, R.; Kaye, I. Modular, High-Volume Fuel Cell Leak-Test Suite and Process (Phase I); Final Technical Report; 2012. Available online: https://www.osti.gov/servlets/purl/1036158 (accessed on 10 September 2019). [CrossRef]

54. Lin, C.-K.; Liu, Y.-A.; Wu, S.-H.; Liu, C.-K.; Lee, R.-Y. Joint strength of a solid oxide fuel cell glass-ceramic sealant with metallic interconnect in a reducing environment. J. Power Sour. 2015, 280, 272-288. [CrossRef]

55. Fairweather, M.J.; Topping, J.A. Alkaline Battery Seal. Patent US 3957538A, 18 May 1976.

56. HyProvide Large-Scale Alkaline Electrolyser [MW], Final Project Report. 2016. Available online: https://www.energiteknologi.dk/sites/energiteknologi.dk/files/slutrapporter/final_report_hyprovide_ 64011-0105_rev_03.pdf (accessed on 10 September 2019).

57. Zito, R., Jr. Zinc-Bromine Battery with Long Term Stability. U.S. Patent US4482614A, 13 November 1984.

58. Nakaishi, H.; Kanno, T.; Ogino, S.; Ito, T.; Shigematsu, T.; Tokuda, N. Cell Frame for Redox-Flow Cell and Redox-Flow Cell. Patent Application US20040202915A1, 14 October 2004.

59. Rongé, J.; Deng, S.; Pulinthanathu Sree, S.; Bosserez, T.; Verbruggen, S.W.; Kumar, S.N.; Dendooven, J.; Roeffaers, M.B.J.; Taulelle, F.; De Volder, M.; et al. Air-based photoelectrochemical cell capturing water molecules from ambient air for hydrogen production. RSC Adv. 2014, 4, 29286-29290. [CrossRef]

(C) 2019 by the authors. Licensee MDPI, Basel, Switzerland. This article is an open access article distributed under the terms and conditions of the Creative Commons Attribution (CC BY) license (http://creativecommons.org/licenses/by/4.0/). 